\section{OPEN ACCESS}

Edited by:

Maurizio Petrelli,

University of Perugia, Italy

Reviewed by:

Cristina Perinelli,

Sapienza University of Rome, Italy

Leonid Danyushevsky,

University of Tasmania, Australia

*Correspondence:

Louise Schoneveld

louise.schoneveld@csiro.au

Specialty section:

This article was submitted to

Petrology,

a section of the journal

Frontiers in Earth Science

Received: 30 January 2020

Accepted: 09 June 2020

Published: 10 July 2020

Citation:

Schoneveld L, Barnes SJ,

Makkonen HV, Le Vaillant $M$,

Paterson DJ, Taranovic V, Wang $K-Y$ and Mao Y-J (2020) Zoned Pyroxenes

as Prospectivity Indicators for

Magmatic Ni-Cu Sulfide

Mineralization. Front. Earth Sci. 8:256.

doi: 10.3389/feart.2020.00256

\title{
Zoned Pyroxenes as Prospectivity Indicators for Magmatic Ni-Cu Sulfide Mineralization
}

\begin{abstract}
Louise Schoneveld $^{1 *}$, Stephen J. Barnes ${ }^{1}$, Hannu V. Makkonen ${ }^{2}$, Margaux Le Vaillant ${ }^{1}$, David J. Paterson ${ }^{3}$, Valentina Taranovic ${ }^{1}$, Kai-Yuan Wang ${ }^{4,5}$ and Ya-Jing Mao ${ }^{6}$

${ }^{1}$ Mineral Resources, Australian Resources Research Centre, CSIRO, Kensington, WA, Australia, ${ }^{2}$ Boliden FinnEx Oy, Sodankylä, Finland, ${ }^{3}$ Australian Synchrotron, ANSTO, Clayton, VIC, Australia, ${ }^{4}$ State Key Laboratory of Ore Deposit Geochemistry, Institute of Geochemistry, Chinese Academy of Sciences, Guiyang, China, ${ }^{5}$ University of Chinese Academy of Sciences, Beijing, China, ${ }^{6}$ Key Laboratory of Mineral Resources, Institute of Geology and Geophysics Chinese Academy of Sciences, Beijing, China
\end{abstract}

Small intrusions dominated by olivine- and pyroxene-rich cumulates are well known to be favorable hosts to magmatic Ni-Cu-(Platinum Group Element-PGE) sulfide mineralization. Such intrusions are common in a variety of settings around the world, but only a very small proportion contain economically exploitable sulfides; these tend to be of conduit or chonolith style. If prospectivity could be discriminated from sparse sampling at early exploration stages, then the discovery rate for deposits of this type could be improved. To this end, a number of pyroxene-bearing samples from small intrusions containing magmatic sulfide deposits have been investigated including the Noril'sk-Talnakh camp in Siberia, the Kotalahti nickel belt in Finland, Ntaka Hill in Tanzania, Nova-Bollinger in the Albany-Fraser Orogen of Australia, Savannah in the Halls Creek Orogen of Australia, Jinchuan in central China, Xiarihamu in Tibet and Huangshanxi in the east Tianshan Ni province of NW China. To compare, samples from unmineralized intrusions in four of these regions were also investigated along with four mafic intrusions from other localities that are not associated with any known economic sulfide mineralization. Using fine-scale $(<5 \mu \mathrm{m} /$ pixel) chemical imaging on the Australian Synchrotron, complex zoning in chromium was found in cumulate and poikilitic pyroxenes within the strongly mineralized intrusions. The zoning patterns can be separated into three distinct types: (1) abrupt zoning: a single change in trace element concentration with a sharp boundary; (2) sector zoning: hourglass style zonation; and (3) oscillatory zoning: small scale oscillations that are usually cyclic. Zoning of all three types can be present in a single grain. The presence of cumulus orthopyroxene with a combination of abrupt zoning, sector zoning and resorbed olivine inclusions has so far only been detected in mineralized intrusions. This combination of zoning patterns is postulated to be an indication of high magma flux and fluctuating cooling rates that accompany wall rock assimilation in dynamic conduits where sulfide liquid forms and accumulates. The distinctive zoning patterns reported here can, in many cases, be easily imaged using desktop microbeam XRF mapping techniques and may provide a useful fertility indicator for the exploration of new magmatic Ni-Cu-(PGE) deposits. 


\section{INTRODUCTION}

Magmatic Ni-Cu-sulfide mineralization is often associated with conduit-style or chonolith-style intrusions (Ripley and Li, 2011; Barnes et al., 2017a; Barnes and Robertson, 2019) that contain pyroxenites or other pyroxene-rich cumulates. These pyroxenites, such as those described in Huangshanxi, China (Mao et al., 2019) and Ntaka, Tanzania (Barnes et al., 2016b), commonly contain large, sometimes poikilitic pyroxenes that trap early cumulus olivine and chromite and preserve zoning of $\mathrm{Cr}$ (Barnes et al., 2019a). Chromium is highly compatible in pyroxene (Ewart et al., 1973; Barnes, 1986; Hart and Dunn, 1993; Lundstrom et al., 1998; Frei et al., 2009; Schoneveld, 2017) which allows $\mathrm{Cr}$ zoning patterns to track changes in magma chemistry during pyroxene growth. Pyroxenes generally have fast growth rates $\left(10^{-7}-10^{-8} \mathrm{~cm} / \mathrm{s}\right)$ (Ubide and Kamber, 2018) which has allowed zoning in pyroxenes in volcanic systems to be a useful proxy to record changes in magmatic conditions (Welsch et al., 2016; Ubide and Kamber, 2018; Ubide et al., 2019). As the diffusion of $\mathrm{Cr}$ is extremely slow (Cherniak and Dimanov, 2010), Cr-zonation in pyroxenes is an effective time capsule that can reveal cryptic cooling and crystallization histories in mafic-ultramafic magmatic systems. Potentially, this gives us a tool to compare the magmatic histories of mineralized and unmineralized systems.

In this contribution we discuss and compare the various types of Cr-zonation of pyroxenes in the mineralized intrusions from a number of economic Ni-Cu magmatic sulfide deposits around the world. These intrusions differ in age, geological setting and metal tenor, but have all been found to display various chemical zonation in pyroxenes. We test the potential application of pyroxene zoning as a prospectivity indicator by comparing the zoning patterns from mineralized (as far as we know), unmineralized or very weakly mineralized intrusions, and intrusions not associated with mineralization from a range of localities.

\section{ZONING IN PYROXENES}

As the pyroxene mineral group has a very large stability field, it usually nucleates early during solidification and can continue to grow for much of the lifetime of mafic-ultramafic intrusions. This allows these minerals to capture the changes in magmatic history within its crystal structure in the form of variable zonation patterns and inclusions. Minor element zonations within both clinopyroxene and orthopyroxene are complex but can be separated into distinct types (Figure 1); (1) normal zoning and reverse zoning (2) sector/hour-glass zoning (3) abrupt zoning (4) oscillatory zoning and finally (5) complex zoning which can incorporate any combination of the previous. Here we discuss the magmatic histories that are indicated by each type of zonation with emphasis on chromium due to its high partitioning and slow diffusion rate in both orthopyroxene and clinopyroxene.

\section{Normal Zonation}

Normal zonation is indicated by a diffuse reduction in chromium (and other compatible elements) concentration toward grain rims (Figure 1A) with a correlated increase in incompatible elements such as $\mathrm{Ti}$ (Bernstein, 2006). Chromium is one of the most compatible elements within both types of pyroxene (Barnes, 1986; Bédard, 2014) which causes it to be depleted as the system evolves. Occasionally, this zonation is reversed to the typical normal zonation, where the concentration of chromium increases toward the rims.

\section{Sector Zoning}

Sector zoning is sometimes referred to as hour-glass or bow-tie zoning due to its characteristic shape (Figure 1B). This type of zonation is common in natural terrestrial (Hollister and Gancarz, 1971; Downes, 1974; Leung, 1974; Welsch et al., 2016), lunar (Hargraves et al., 1970; Hollister et al., 1971) and experimental pyroxene (Lofgren et al., 2006; Schwandt and McKay, 2006).

These sector zones represent differences in chemistry of a crystal due to kinetic effects at the growth surface, whereby elements are incorporated into the structure at different rates along different crystallographic surfaces, rather than changes in chemistry or conditions of the surrounding magma (Hollister and Gancarz, 1971). There are at least four controlling factors for the creation of sector zones, as explained by Hollister and Gancarz (1971); “(1) size and composition of ionic complexes added to the crystal as it grows, (2) rate of addition of material, (3) rate of equilibration of the new material with the matrix at the surfaces of growth steps, and (4) rate of re-equilibration of surface layers with the matrix by exchange of ions perpendicular to the crystal faces." Therefore, these crystals grew fast enough to outrun diffusive equilibration between adjacent growth sectors.

In clinopyroxene, the $\mathrm{M} 1$ and $\mathrm{T}$ sites are exposed on the (010) crystal face whereas either the M1 or the $\mathrm{T}$ sites are exposed on the (100) face (Hollister and Gancarz, 1971). This different exposure of the vacant sites on different faces of the clinopyroxene grains means that the partition coefficients on each face will be different. In the case of the pyroxenes present here, there is a difference in the partitioning of chromium that creates visible sector zoning within both clinopyroxene and orthopyroxene grains. Sector zoning in pyroxenes can lead to false abrupt zoning when viewed in a two dimensional section through the c-axis as illustrated in Welsch et al. (2016) and displayed in Figure 1.

\section{Abrupt Zoning}

Abrupt zoning is characterized by a large change in chemistry over a short distance of crystal growth (Figure 1C). This type of zoning is indicative of two stages of growth. This could indicate either a change in growth environment of the pyroxenes, or a change in chemistry of the magma, where the budget of chromium has been exhausted or the chromium has changed to a less favorable cation (i.e., $\mathrm{Cr}^{3+}$ over $\mathrm{Cr}^{2+}$ ) resulting in a sudden change to a lower partition coefficient (Barnes, 1986). A likely cause of abrupt zoning is a change from crystallization on the liquidus from freely convecting magma to equilibrium crystallization in a restricted closed system in the intercumulus pore space of an orthocumulate, following incorporation of the crystal into a cumulus pile or mush. 


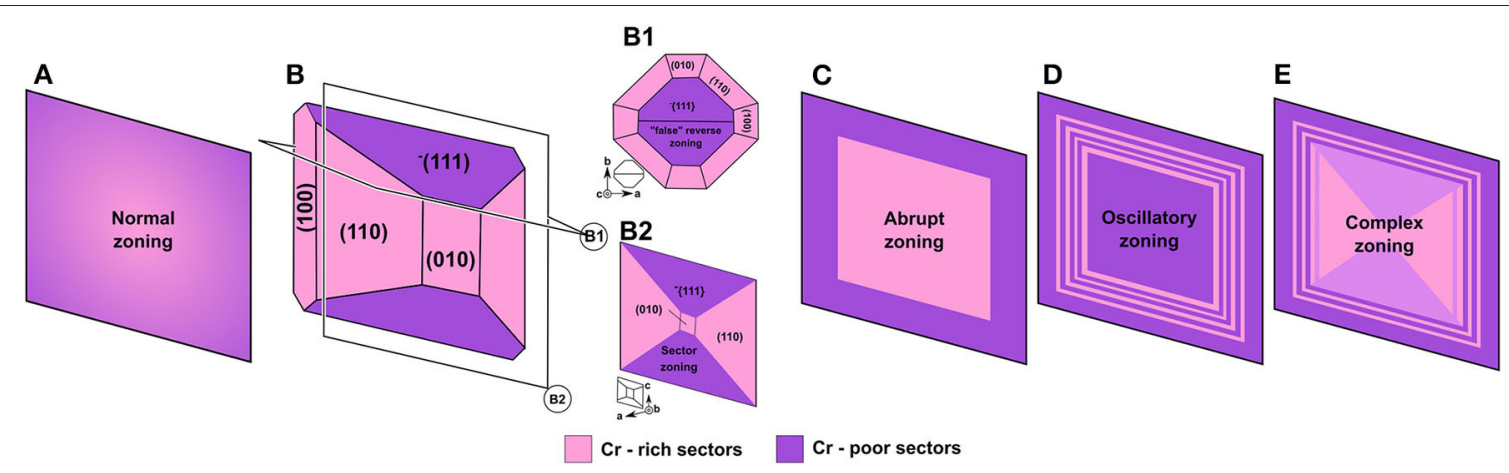

FIGURE 1 | Types of zonation visible in pyroxene. A schematic illustration using Cr content in clinopyroxene to illustrate the zoning types. Normal zoning (A) is common in unmineralized/barren intrusions and is characterized by a diffuse reduction in chromium (and other compatible elements) concentration toward the rims. (B) Sector zoning, hourglass style zonation in $\mathrm{Cr}$ concentration in the core of the pyroxene, Modified from Welsch et al. (2016). Cross sections through the b and c axis give; (B2) hourglass sector-zoned clinopyroxene and (B3) a false-reverse zoned clinopyroxene. (C) Abrupt zoning: a rapid change in the trace element chemistry between the core and rim (D) oscillatory zoning: repetitive cycles of chemistry change within the crystal. (E) Complexly zoned pyroxene can be made up of a combination of (B-D).

\section{Oscillatory Zoning}

Oscillatory zoning is the repetitive or cyclic change in chemistry of the crystal during growth. There are two possible causes for the formation of oscillations of chemistry during crystal growth as outlined by Fowler and Shore (1996); (1) extrinsic causes such as changes in pressure $(\mathrm{P})$, temperature $(\mathrm{T})$ or magma composition (X) or (2) intrinsic causes such as fluctuations between diffusive and advective supply of cations in a melt boundary layer immediately adjacent to the growing crystal.

Fowler and Shore (1996) suggest that oscillatory zoning is favored in silicates of "moderately rapid growth" i.e., growing between $10^{-11}$ and $10^{-13} \mathrm{~m} / \mathrm{s}$.

\section{Complexly Zoned Pyroxenes}

A complexly zoned pyroxene in the context of this manuscript is any combination of sector, abrupt and oscillatory zoning of chromium within a clinopyroxene or orthopyroxene.

\section{SAMPLES}

We investigate samples from eleven economically mineralized magmatic $\mathrm{Ni}-\mathrm{Cu}$ sulfide intrusions from regions including; the Noril'sk-Talnakh camp in Siberia, the Kotalahti nickel belt in Finland, Ntaka Hill in Tanzania, Nova-Bollinger in the AlbanyFraser Orogen of Australia, Savannah in the Halls Creek Orogen of Australia, Jinchuan in central China, Xiarihamu in Tibet, and Huangshanxi in the east Tianshan Ni province of NW China (Table 1).

In addition to these significantly mineralized intrusions, we compare intrusions within the same region that contain "weak" (usually sparsely disseminated) mineralization to those that show no evidence of magmatic sulfides ("barren").

Finally, we investigate four mafic intrusive bodies that are not associated with any known economic mineralization to determine "background" textural and chemical features that are not specifically relatable to mineralization. These samples include the Ngunala (previously referred to as Caroline) intrusion and the Wanka Wanka dyke in the East Musgrave province of Central Australia, the Archean Ora Banda sill and the Proterozoic Jimberlana Dyke, both in the East Yilgarn Craton of Australia. It should be noted that a possibility exists for "false negatives" in that some of the bodies sampled and placed in the "weak" or "barren" categories have not been extensively explored and could subsequently tun out to contain economic mineralization at depth; this problem is endemic to this kind of study and we can only use the information currently available.

More details of these samples are included in Table $\mathbf{1}$ and full details and references for the deposits, intrusions and samples are included in the Supplementary Material.

\section{METHODS}

The samples were fashioned into 30 or $100 \mu \mathrm{m}$ thin sections, mounted on either quartz or standard petrographic glass slides.

\section{Synchrotron, Maia Mapper, and Desktop X-Ray Fluorescence Imaging}

Multiple experiments on the XFM beamline at the Australian Synchrotron, operated by ANSTO were carried out between 2015 and 2019. The common method used in these experiments is scanning with a pixel size of $4^{*} 4 \mu \mathrm{m}$, a movement speed of $5 \mathrm{~mm} / \mathrm{s}$ and a dwell of $0.8 \mathrm{~ms}$, though this method varied depending on target area, grain size and available time. The images were collected on a Maia 384 detector array using the Kirkpatrick Baez mirror microprobe end-station. We used a monochromatic $2 \mu \mathrm{m}$ beam spot size for at an energy of $18,500 \mathrm{eV}$. The collected spectra were then processed by the GeoPIXE software into element concentrations presented as maps of quantified element concentrations with spectral overlap, pileup and background removed using the Dynamic Analysis (DA) method for real-time spectral deconvolution (Ryan, 2000; Kirkham et al., 2010; Ryan et al., 2014).

To increase the detection limit for $\mathrm{Cr}$ and Ti via XRF, we also reduced the energy of the synchrotron $\mathrm{X}$-rays to $7,050 \mathrm{eV}$ which 
TABLE 1 | Representative samples from each intrusion.

\begin{tabular}{|c|c|c|c|c|c|c|c|c|c|c|}
\hline Location & Intrusion & Sample & Rock type & Category & $\begin{array}{l}\text { Primocryst cumulus } \\
\text { phase* }\end{array}$ & Oikocrysts & Chadacrysts & Zoning CPX & Zoning OPX & Comment \\
\hline $\begin{array}{l}\text { Iberian pyrite belt, } \\
\text { Spain }\end{array}$ & Aguablanca & AB-NA1 & Pyroxenite breccia & ED-S & $\begin{array}{l}\text { Clinopyroxene, sulfide } \\
\text { liquid }\end{array}$ & & & Reverse zoning & Exsolution & $\begin{array}{l}\text { Disaggregated } \\
\text { pyroxenite in magmatic } \\
\text { sulfide liquid matrix }\end{array}$ \\
\hline $\begin{array}{l}\text { East kunlun } \\
\text { orogenic belt, tibet }\end{array}$ & Xiarihamu & QX14-23-14 & Lherzolite & ED-M & Olivine, chromite, opx & & & NA & Abrupt, osc. & $\begin{array}{l}\text { Small olivine inclusions } \\
\text { in cumulus opx }\end{array}$ \\
\hline $\begin{array}{l}\text { East Tianshan Ni } \\
\text { province, NW } \\
\text { China }\end{array}$ & Huangshanxi & 06-18-908 & Harzburgite & ED-S & $\begin{array}{l}\text { Olivine/orthopyroxene, } \\
\text { chromite }\end{array}$ & opx & Chromite, olivine & Sector, abrupt & $\begin{array}{l}\text { Sector, abrupt, } \\
\text { reverse rim }\end{array}$ & $\begin{array}{l}\text { Small olivine inclusions } \\
\text { in cumulus opx }\end{array}$ \\
\hline \multirow{9}{*}{$\begin{array}{l}\text { Kotalahti Ni belt- } \\
\text { Raahe-ladoga belt } \\
\text { (Svecofennian), } \\
\text { Finland }\end{array}$} & Majasaari & KU27906 & plagioclase - peridotite & Barren & Olivine, chromite & & & Weak sector, normal & Weak sector, normal & \\
\hline & Kekonen & KU07018 & $\begin{array}{l}\text { peridotite (+ } \\
\text { serpentine) }\end{array}$ & ED-S & Olivine, opx & & & $\begin{array}{l}\text { Normal (cpx at the } \\
\text { expense of opx) }\end{array}$ & Sector, abrupt & $\begin{array}{l}\text { Small olivine inclusions } \\
\text { in cumulus opx }\end{array}$ \\
\hline & Rytky & KU30024 & Peridotite & ED-S & Olivine, sulfide liquid & & & Abrupt, osc., sector & Abrupt, osc. & \\
\hline & & KU30025 & Peridotite & ED-S & Olivine & $\mathrm{cpx}$ & Olivine & Abrupt, osc., sector & Abrupt, osc. & \\
\hline & & KU30063 & Pyroxenite & ED-S & Orthopyroxene & $\mathrm{cpx}$ & $o p x$ & Sector, osc., normal & Sector, abrupt & \\
\hline & Niinimaki & KU23620 & Serpentinite & Minor & Olivine, chromite & opx & Chromite, olivine & None & Normal & \\
\hline & Saarijarvi & KU06937 & Peridotite-Iherzolite & Minor & Olivine/chromite & opx & Chromite, olivine & None & Normal & \\
\hline & Ylivieska & KU25187 & Olivine gabronorite & Minor & Olivine, plagioclase & & $\begin{array}{l}\text { Olivine, } \\
\text { plagioclase }\end{array}$ & Normal & NA & \\
\hline & Saarela & KU30145 & Norite & Minor & Orthopyroxene & & & None & Weak sector, abrupt & \\
\hline $\begin{array}{l}\text { Longshoushan } \\
\text { terrane, gansu, } \\
\text { China }\end{array}$ & Jinchuan & JII-II & Lherzolite & ED-M & Olivine/orthopyroxene & & & Sector & Sector, abrupt, osc. & \\
\hline \multirow{8}{*}{$\begin{array}{l}\text { Norilsk region, } \\
\text { siberia }\end{array}$} & Kharealakh & KH-2_map1 & Picro-gabbrodolerite & ED-M & Olivine & $\mathrm{cpx}$ & Olivine & Sector, normal & NA & \\
\hline & Norilsk-1 & N1-24-93.6 & $\begin{array}{l}\text { "Taxite" - } \\
\text { contaminated gabbro, } \\
\text { dolerite }\end{array}$ & ED-M & Chromite/olivine & & & $\begin{array}{l}\text { Sector, adrupt, weak } \\
\text { osc. }\end{array}$ & $<\mathrm{NA}$ & \\
\hline & & NOR1-1A & $\begin{array}{l}\text { Gabbro, olivine } \\
\text { gabbro, wehrlite } \\
\text { ("picrogabbrodolerite") }\end{array}$ & ED-M & Olivine & $\mathrm{cpx}$ & Olivine & Normal & Normal & \\
\hline & Kharealakh & VZU-3B & & ED-M & Olivine & & & Abrupt, osc. & NA & \\
\hline & AlloreRiver & BX2_2438.7 & & Minor & Plagioclase & $\mathrm{cpx}$ & Plagioclase & Weak sector, abrupt & NA & \\
\hline & Lower Talnakh & TR31_797.4 & & Minor & Olivine & $\mathrm{cpx}$ & $\begin{array}{l}\text { Olivine, } \\
\text { plagioclase }\end{array}$ & Weak sector, normal & NA & \\
\hline & & TR31_798.7 & & Minor & Olivine & & & Weak sector, abrupt & NA & \\
\hline & Chernogorsk & UK35-229.9 & & Minor & Olivine & $\mathrm{cpx}$ & Plagioclase & Weak sector, normal & NA & \\
\hline $\begin{array}{l}\text { Albany fraser } \\
\text { orogen }\end{array}$ & Nova & N614-5 & Lherzolite & ED-S & Olivine & opx & Olivine & Sector, osc. & Sector & \\
\hline
\end{tabular}


TABLE 1 | Continued

\begin{tabular}{|c|c|c|c|c|c|c|c|c|c|c|}
\hline Location & Intrusion & Sample & Rock type & Category & $\begin{array}{l}\text { Primocryst cumulus } \\
\text { phase* }^{*}\end{array}$ & Oikocrysts & s Chadacrysts & Zoning CPX & Zoning OPX & Comment \\
\hline & & $\begin{array}{l}\text { SFRD0111- } \\
169\end{array}$ & & ED-S & Olivine, Cr-spinel, opx & opx & Olivine & Adrupt & Sector & \\
\hline & & $\begin{array}{l}\text { SFRD0272- } \\
390\end{array}$ & & ED-S & $\begin{array}{l}\text { Olivine, Cr-spinel, } \\
\text { orthopyroxene }\end{array}$ & & & Normal & Sector, abrupt & $\begin{array}{l}\text { Extensive } \\
\text { olivine-plagioclase } \\
\text { reaction coronas } \\
\text { (amph-spinel } \\
\text { symplectites) }\end{array}$ \\
\hline & Upper Nova & SFRD0017_49 & Peridotite & Minor & Olivine, Cr-spinel & $\mathrm{cpx}$ & Olivine & Normal & Normal & $\begin{array}{l}\text { Extensive } \\
\text { olivine-plagioclase } \\
\text { reaction coronas } \\
\text { (amph-spinel } \\
\text { symplectites) }\end{array}$ \\
\hline \multirow[t]{2}{*}{$\begin{array}{l}\text { Mozambique } \\
\text { mobile belt }\end{array}$} & Ntaka hill & Ntaka-8321 & Harzburgite & ED-S & Orthopyroxene & & & None & Reverse abrupt & $\begin{array}{l}\text { Small olivine inclusions } \\
\text { in cumulus opx }\end{array}$ \\
\hline & & Ntaka-8386 & Harzburgite & ED-S & Orthopyroxene & & & None & Sector, abrupt, osc. & $\begin{array}{l}\text { Small olivine inclusions } \\
\text { in cumulus opx }\end{array}$ \\
\hline \multirow[t]{2}{*}{ Halls creek orogen } & Turkey creek & TCDM01 & Gabbronorite & Barren & Plagioclase, opx & & & Exsolution, normal & Exsolution, normal & Probably non-cumulate \\
\hline & Savannah & EK2366 & Norite & ED-S & Orthopyroxene & & & None & Exsolution, normal & \\
\hline \multicolumn{11}{|c|}{ INTRUSIONS UNRELATED TO NI-SULFIDE MINERALIZATION } \\
\hline $\begin{array}{l}\text { East musgrave } \\
\text { province (S } \\
\text { Australia) }\end{array}$ & $\begin{array}{l}\text { Ngunala } \\
\text { (Caroline) }\end{array}$ & $\begin{array}{l}\text { DD10WOD002- } \\
131\end{array}$ & - Pyroxenite & VMD & Orthopyroxene & $\mathrm{cpx}$ & opx & None & None & \\
\hline $\begin{array}{l}\text { Widgiemooltha } \\
\text { dike swarm }\end{array}$ & Jimberlana & A65 & Pyroxenite & VMD & Orthopyroxene & $\mathrm{cpx}$ & opx & Normal & Weak sector, normal & \\
\hline $\begin{array}{l}\text { Kalgoorlie terrane } \\
\text { (Archean Yilgarn } \\
\text { Craton) }\end{array}$ & OraBanda & OB1 & Pyroxenite & VMD & Orthopyroxene & $\mathrm{cpx}$ & opx & Abrupt, normal & Normal & \\
\hline $\begin{array}{l}\text { East musgrave } \\
\text { province (S } \\
\text { Australia) }\end{array}$ & WankaWanka & WW3_150 & Lherzolite & Barren & Olivine & cpx, opx & olivine & osc., normal & osc., normal & \\
\hline Bushveld complex & Bushveld & BV9 & & VMD & $\begin{array}{l}\text { Orthopyroxene, } \\
\text { chromite }\end{array}$ & $\mathrm{cpx}$ & Chromite, opx & Normal & None & \\
\hline
\end{tabular}

Oscillatory zoning abbreviated to osc. NA is "not applicable" which indicates the phase is not present. *Euhedral to subidiomorphic habit, usualy forming framework of touching grains, with small proportion of inclusions, or no inclusions (Irvine, 1982); magmatic sulfide is also a cumulus phase in some of these samples, but occurs as interstitial aggregates. Mineralization code: ED-S, economic deposit, small; ED-M, economic deposit, major; Minor, minor disseminated, sub-economic; VMD, trace to very minor disseminated sulfide, not economic. Data sources (Keays and Campbell, 1981; Chai and Naldrett, 1992; Witt, 1995; Makkonen, 1996; Mäkinen and Makkonen, 2004; Makkonen and Mursu, 2004; Li et al., 2005; Song et al., 2012; Makkonen et al., 2017). This table is extended in the Supplementary Material to include the method for the synchrotron data and details of the intrusions. 
is below the absorption edge for Fe. This increases the resolution of these zoning patterns significantly as shown in Barnes et al. (2020).

The major element data obtained via the synchrotron XRF is in good agreement $\left(r^{2}=0.97\right)$ with the data obtained by electron probe microanalyzer (EPMA) for the same regions on sample KU30024 (Figure 2), however, the high energy scans have high errors for trace $\mathrm{Cr}$ concentrations due to noise in the X-ray signal. Comparing a traverse across the same grain (KU27906) from the high energy experiment $(18,500 \mathrm{eV})$ and the low energy experiment $(7,050 \mathrm{ev})$ the data is within error, with the low energy results giving much higher precision than the high energy experiment.

Desktop microbeam XRF mapping was also used to determine if these zoning patterns can be observed using more widely available technology. The XRF mapping was conducted using a Bruker desktop microbeam XRF mapper-M4 Tornado $^{\mathrm{TM}}$, at CSIRO Mineral Resources, Western Australia. The device is equipped with a rhodium $\mathrm{X}$-ray tube which was set to 50 $\mathrm{kV}$ and $500 \mathrm{nA}$ and an XFlash ${ }^{\circledR}$ silicon drift X-ray detector. Maps were created using a $40 \mu \mathrm{m}$ spot size on a $40 \mu \mathrm{m}$ raster with dwell times of $5 \mathrm{~ms}$ per pixel. Element maps represent the unquantified background corrected peak height data for $\mathrm{K} \alpha$ peaks for each element, scaled either linearly or logarithmically between minimum and maximum measured counts over the sample. The elements were then stacked in red-green-blue (RGB) colored images. It should be noted that minor element maps generated using the Tornado device are highly susceptible to diffraction artifacts, causing spurious appearances of high concentrations due to crystal orientations relative to source and detector that correspond to Bragg angles. As this is extremely common, they have been included and clearly labeled in this manuscript (for an example see Figure 6B) in an attempt to avoid misinterpretation of these features. Use of the multi-detector Maia array overcomes this problem.

\section{MINERALIZED INTRUSIONS}

The Rytky intrusion of the Kotalahti Ni-belt in Finland (Makkonen, 2015) has both orthopyroxenes and clinopyroxenes that are very large $(\sim 1 \mathrm{~cm})$ and both show significant abrupt zonation. The clinopyroxene grain examined in Figure 3A has distinct sector zoning and oscillations in $\mathrm{Cr}$ in the rims and contains olivine inclusions. The traverse through this clinopyroxene grain shows core values of $\sim 4000-6000$ ppm $\mathrm{Cr}$ near the olivine inclusions with a rapid decrease to near zero (Figure 4A) in the Cr-poor rims. The outer zones display oscillations in $\mathrm{Cr}$; however, these are of much lower concentration $(<1,000 \mathrm{ppm})$ than the core. Both $\mathrm{Mn}$ and $\mathrm{Ti}$ increase in the outer $1,000 \mu \mathrm{m}$ of this clinopyroxene grain. Orthopyroxenes from this intrusion also display abrupt changes from core to rim and oscillations in $\mathrm{Cr}$ content in the rims (Figure 5). The abrupt change from core to rim is difficult to quantify as the crystals are different sizes and we are analyzing traverses through a random cross section of the crystal, therefore

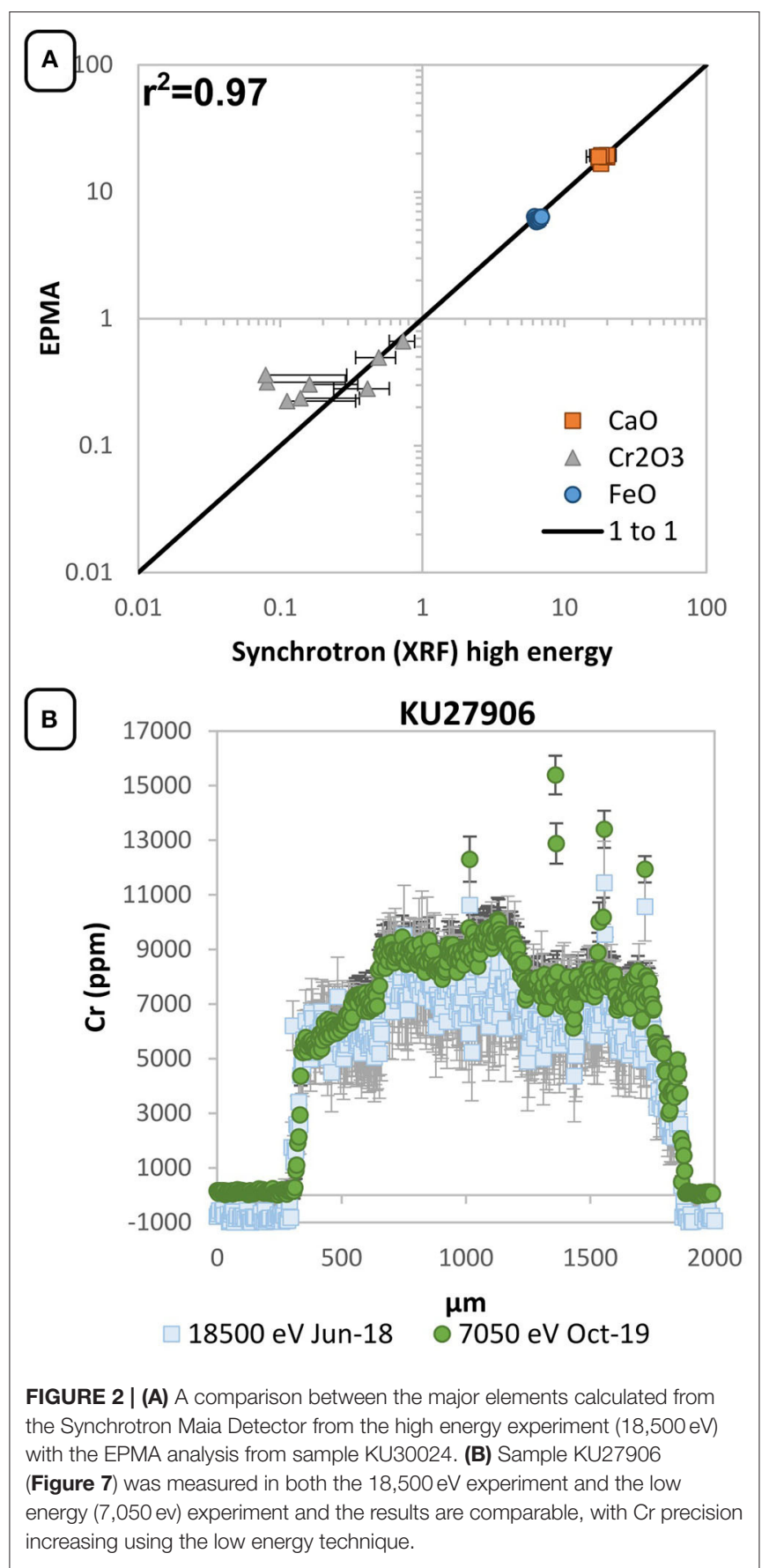

the relative distance that the crystal changes from high to low concentrations can change greatly (Figure 5).

The Ntaka Hill intrusion was described in detail in Barnes et al. (2016b, 2019b). Sample Ntaka-8,321 is a harzburgite and shows abrupt zoning of $\mathrm{Cr}$ in all the large $(\sim 4 \mathrm{~mm})$ orthopyroxenes (Figure 3B). There are also fine scale oscillations throughout the core of the grains and slight sector zonation. Ntaka Hill pyroxenites and harzburgites also show widespread abrupt zonation, where partially resorbed olivine inclusions are preferentially located at the edges of the Cr-enriched cores 


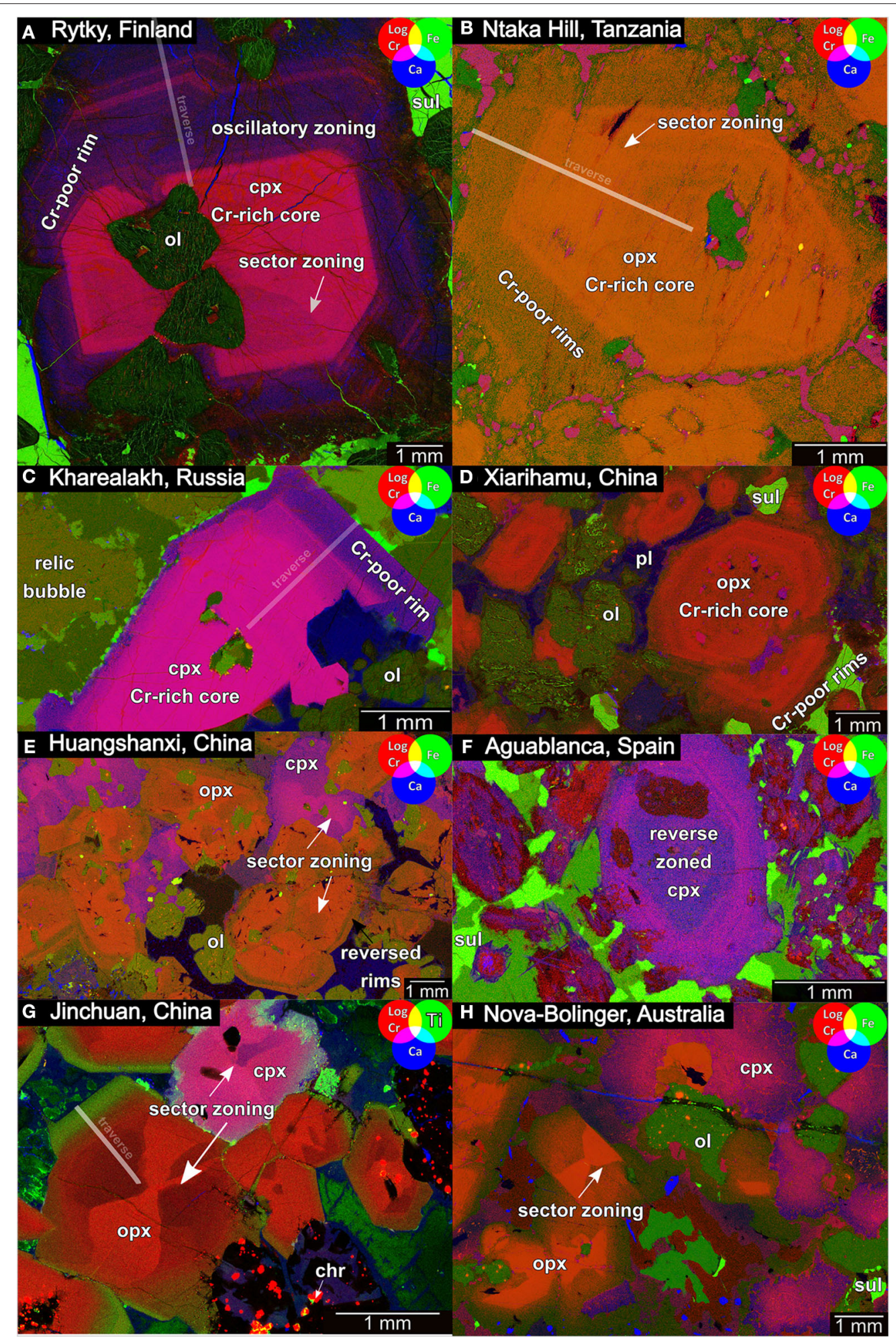

FIGURE 3 | X-ray Fluorescence (XRF) images collected from the Australian Synchrotron of zoned pyroxenes in Ni-Cu magmatic sulfide deposits from around the world. (A) Rytky, (B) Ntaka Hill, (C) Kharealakh (Talnakh), (D) Xiarihamu, (E) Huangshanxi, (F) Aguablanca, (G) Jinchuan, and (H) Nova-Bollinger. Stacked false color (RGB) image of logged chromium concentration in red, iron or titanium in green and calcium in blue. Clinopyroxene [Ca(Mg,Fe)Si $\left.\mathrm{O}_{6}\right]$ is displayed in pink (Cr-rich) to purple ( $\mathrm{Cr}$-poor) while orthopyroxene $\left[(\mathrm{Mg}, \mathrm{Fe}) \mathrm{SiO}_{3}\right]$ is orange (Cr-rich) to green (Cr-poor) in colouration. Mineral abbreviations: cpx, clinopyroxene; ol, olivine; opx, orthopyroxene; pl, plagioclase; S, sulfide. 

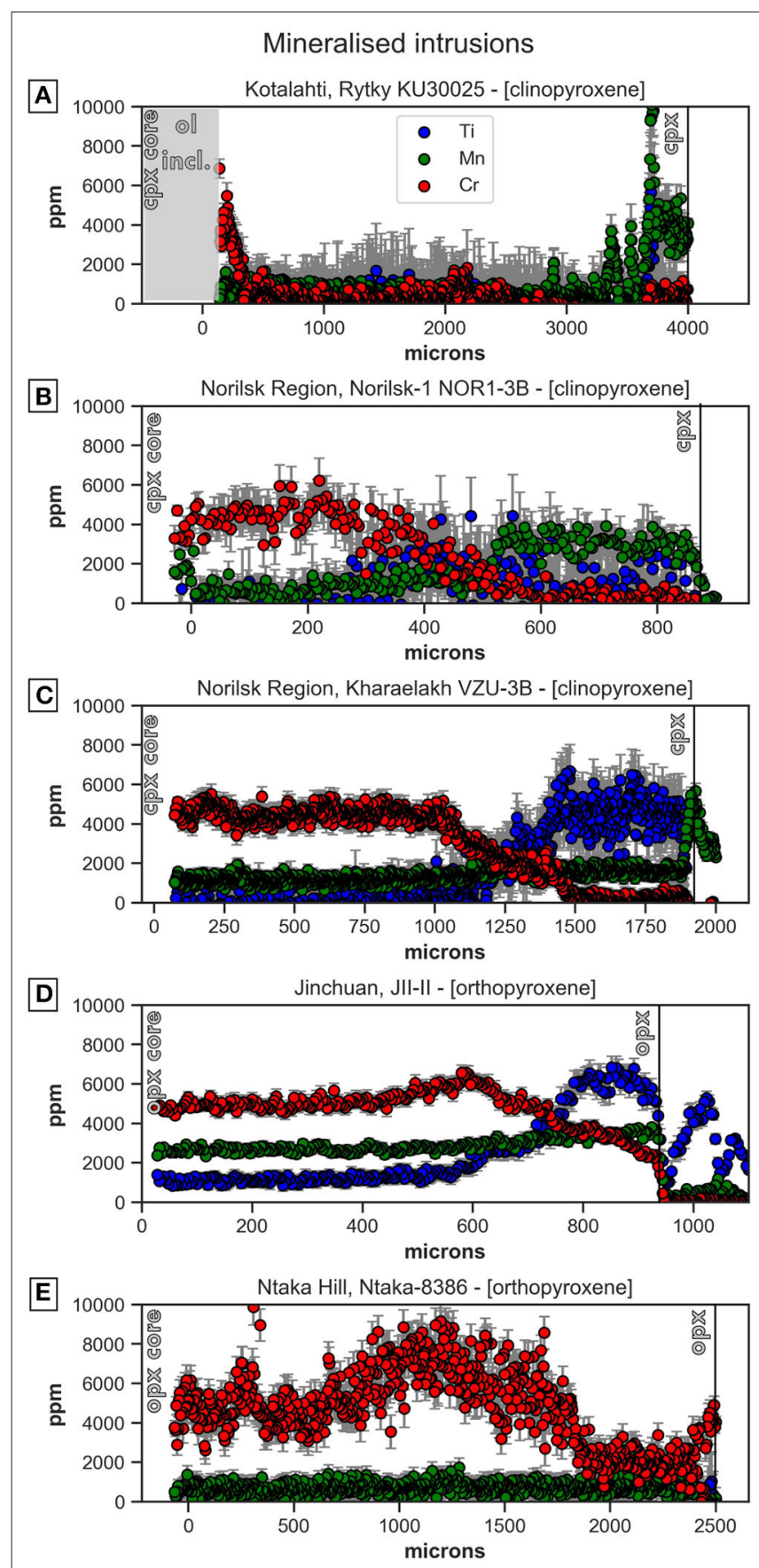

FIGURE 4 | Traverses across clinopyroxene and orthopyroxene from core to rim in mineralized intrusions. (A) Traverse through clinopyroxene from the Rytky intrusion, Kotalahti Ni-belt (Figure 3A). (B) Clinopyroxene from the Norilsk-1 intrusion of the Norilsk-Talnkah region. (C) Clinopyroxene from the Kharaelakh intrusion of the Norilsk-Talnakh region (Figure 3C). (D) An orthopyroxene from Jinchuan intrusion (Figure 3G). (E) An orthopyroxene from the Ntaka Hill intrusion in Tanzania (Figure 3B).

(Barnes et al., 2016b), and less common reverse zoning toward Cr-enriched rims. A traverse along an orthopyroxene grain was undertaken in a high energy scan on the synchrotron (lower precision in these minor elements than the low energy scans) and shown in Figure 4E. An enrichment in $\mathrm{Cr}$ is observed from the core toward the abrupt zone ( $\sim 4,000-8,000 \mathrm{ppm})$, which drops to the $\mathrm{Cr}$ poor rims ( $2000 \mathrm{ppm})$.

The intrusions of the Norilsk-Talnakh region: Kharaelakh, Talnakh and Norilsk 1, are known to be anomalously orthopyroxene-poor. Examining one of the clinopyroxene grain from the Kharaelakh intrusion (Figure 3C), there is an abrupt zonation between the Cr-rich core $(\sim 4,500 \mathrm{ppm})$ and the Cr-poor (near zero) rim (Figure 4C). Clinopyroxenes in this sample commonly host olivine and chromite inclusions which represent the first phases crystallizing in this system (Schoneveld et al., 2020). This sample was included in the detailed investigation of blebby sulfides from Norilsk of Barnes et al. (2019a) and Le Vaillant et al. (2017).

The intrusions of the Xiarihamu deposit were discussed in detail in Wang et al. (2019). The Cr-rich core of the orthopyroxene grain in Figure 3D shows oscillations and also contains small clinopyroxene inclusions.

The samples from both Huangshanxi and Aguablanca display examples of "reverse zoning" where the concentration of chromium increases in the outer mantle of the grains. The sample from Huangshanxi (Figure 3E) was discussed in detail in Mao et al. (2019). The sample is made up of mostly sector zoned orthopyroxenes and clinopyroxenes with some plagioclase, olivine and sulfide. The orthopyroxene grains examined in Figure 3E show a mantle of lower $\mathrm{Cr}$ values which is not reflected in the adjacent clinopyroxene grains. Both pyroxenes contain small olivine inclusions. The sample from Aguablanca (Figure 3F) was discussed in Barnes et al. (2018). This sample is made up of mostly sulfides and many clinopyroxenes with reverse and oscillatory zoning; where the core of the clinopyroxene grains are low in $\mathrm{Cr}$ and there is a $\mathrm{Cr}$ rich mantle which reduces to a Cr-poor rim.

The sample from Jinchuan (Figure 3G) shows strong sector zoning in both pyroxene types with an abrupt Cr-poor, Ti-rich rim in the orthopyroxenes. General information on the crystal growth in these intrusions is included in Mao et al. (2018). A traverse along one of these orthopyroxene grains (Figure 4D) shows a slight increase in $\mathrm{Cr}(4,500-6,000 \mathrm{ppm})$ then a rapid decrease in to $2,000 \mathrm{ppm}$ over outer $300 \mu \mathrm{m}$ of the rim. This latter decrease in $\mathrm{Cr}$ is correlated to an increase in $\mathrm{Ti}$ from 1,000-6,000 ppm.

The sample from the mineralized Lower Intrusion at NovaBollinger (Barnes et al., in press) (Figure 3H) contains sector zoned orthopyroxenes with sharply-defined rims that reduce to near zero $\mathrm{Cr}$ concentrations. The Cr-rich orthopyroxene cores commonly contain olivine inclusions. The clinopyroxenes exhibit a diffuse change from core to rim. This sample is also host to olivine-plagioclase reaction coronas that include a second generation of orthopyroxenes forming symplectite intergrowths with spinel.

In addition to these large, complexly zoned pyroxenes, many of the mineralized intrusions have clinopyroxene or orthopyroxene oikocrysts (Barnes et al., 2016b, 2019a). These are very large $(>5 \mathrm{~mm})$ single crystals that enclose many 

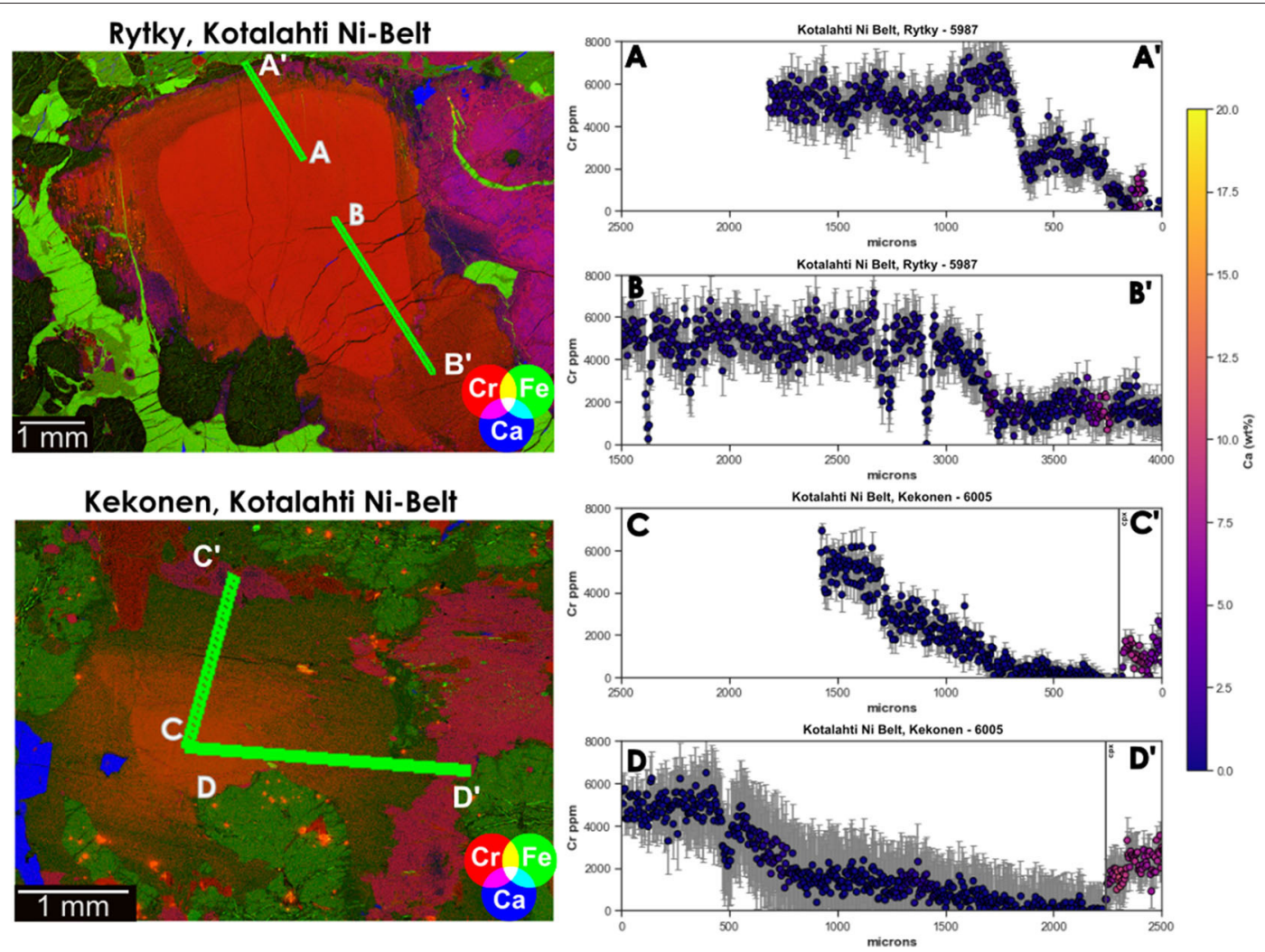

FIGURE 5 | Traverses through abrupt zonation in orthopyroxene (opx) grains. Traverse (A,B) are on an orthopyroxene from Rtyky while (C,D) are from the Kekonen intrusion. Both samples are from Kotalahti Ni-belt. The degree of abrupt zonation may depend on crystal orientation. The sector zoning in the second grain represents looking down the $\mathbf{( C )}$ axis. Therefore (C,D) are traverses approximately along with $(\mathbf{A}, \mathbf{B})$ axis. Each traverse is cropped to a total of 2,500 um and presented as core to rim traverses so we can directly compare between traverses. Color scheme is wt\% Ca content of the analysis to ensure orthopyroxene composition with no inclusions.

small crystals; usually either pyroxene (Figure 6A) or olivine (Figure 6B). These oikocrysts also display $\mathrm{Cr}$ sector zoning.

In general, these mineralized intrusions are all made up of olivine, pyroxene and plagioclase with additional phases including chromite and sulfide. The pyroxenes are generally large ( $>1 \mathrm{~mm}$ ), commonly host olivine inclusions and have abrupt zoning of $\mathrm{Cr}$ and usually sector zoning.

\section{UNMINERALIZED INTRUSIONS}

The "unmineralized" classification of intrusions represent both intrusions with no sulfides present (barren) as well as intrusions that contain a small quantity of sulfides (weakly mineralized).

In general, these intrusions have less orthopyroxene than their mineralized counterparts (with the exception of Norilsk-Talnakh where the mineralized intrusions are unusually orthopyroxenepoor) and gradational normal zonation in $\mathrm{Cr}$ in both pyroxene species. This normal zonation is characterized by the gradual increase of incompatible trace elements toward the crystal edges which represents gradual depletion of highly compatible $\mathrm{Cr}$ during progressive equilibrium crystallization from the trapped liquid. The low energy method (Barnes et al., 2020) allows observation at high sensitivities for $\mathrm{Cr}$ and $\mathrm{Ti}$ to distinguish very subtle changes in chemistry. Pyroxenes from the unmineralized or weakly mineralized intrusions display weak sector zonation that is only visible in the low energy scanning mode as the differences in the concentration between the zones is minimal.

A number of intrusions were investigated from the Kotalahti Ni-belt (Makkonen, 2015) which range from barren (Majasaari, Figure 7A), some indications of mineralization (Saarela, Figure 7B) to weakly mineralized (Saarijarvin, Figure 7C). The barren Majasaari intrusion is made up of olivine, plagioclase and chromite with large $(>3 \mathrm{~mm}$ ) clinopyroxene and orthopyroxene grains. The pyroxenes enclose small olivine and chromite grains and the clinopyroxene displays faint sector zoning, as displayed by the grain in Figure 7A. The Saarela intrusion samples are predominantly plagioclase-rich cumulates with some clinopyroxene and orthopyroxene grains. The orthopyroxenes are $\sim 1 \mathrm{~mm}$ in size and have an enrichment of chromium throughout some of the grains. The weakly mineralized Saarijarvin intrusion has very large $(>8 \mathrm{~mm})$ normally zoned orthopyroxenes that enclose olivine chadacrysts (Figure 7C). The concentration of $\mathrm{Ti}$ in the orthopyroxene grain in Figure $7 \mathrm{C}$ increases from 2,400 ppm in the core to $\sim 5,000 \mathrm{ppm}$ toward the rims while $\mathrm{Cr}$ decreases from 6,800 to $\sim 3,000 \mathrm{ppm}$ toward the rims (Figure 8). 


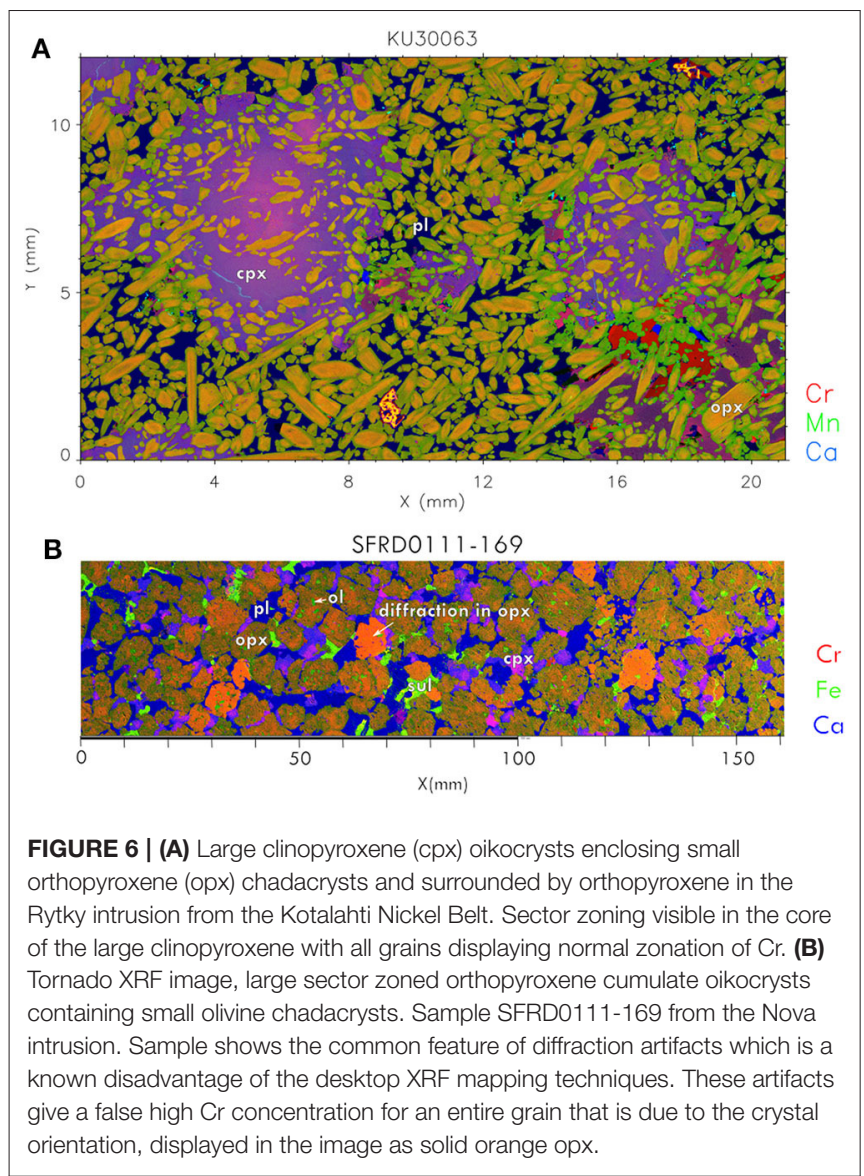

The Turkey Creek intrusion (near Savannah) and the upper Nova intrusion show limited Cr zoning in pyroxene oikocrysts. The Upper Intrusion at Nova shows a good example of normal zonation in both clinopyroxene and orthopyroxene grains (Figures 7E, 8). The Turkey Creek sample shows large clinopyroxene grains with smaller orthopyroxene exsolutions in their cores (Figure 7D).

The unmineralized intrusions from Norilsk-Talnakh show weak sector zoning in the cores of the clinopyroxenes which also contain plagioclase inclusions. These intrusions also show a diffuse zonation between the Cr-rich cores and the Cr-poor rims (Figures 7, 8).

There is a small possibility that these "barren" intrusions are under-explored and may eventually turn out to contain significant mineralization following further exploration; therefore, we also investigate pyroxenes from mafic intrusions that are not associated with any known mineralization (other than minor marginal disseminations) on a regional scale.

\section{MAFIC INTRUSIONS}

These intrusions are associated with the presence of at most very minor, uneconomic magmatic sulfides, however, the pyroxenes within these intrusions still exhibit zonation from which we can infer their magma history.
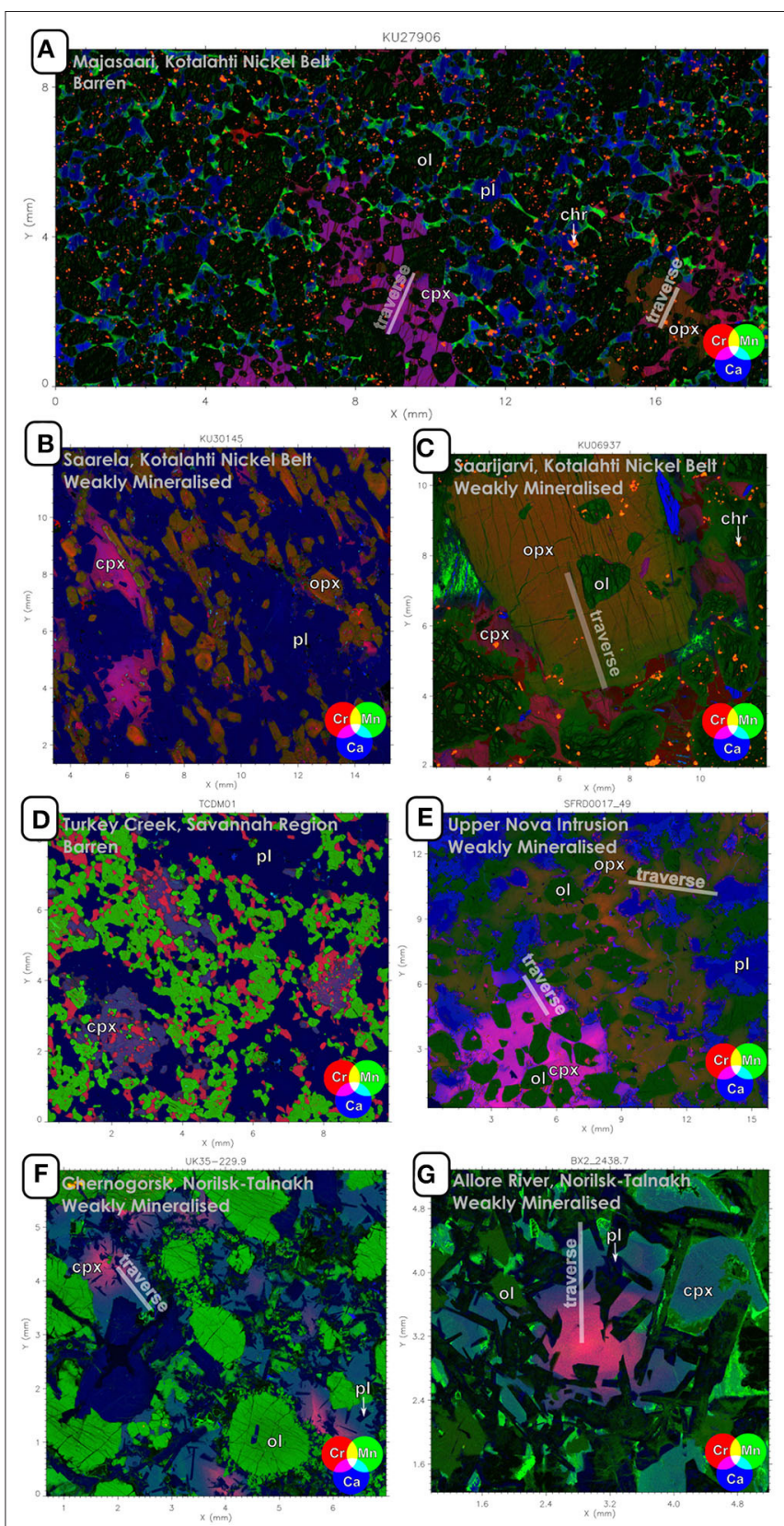

FIGURE 7 | Concentric normal zonation (Cr-rich core, Cr-poor rim) in pyroxene from reactions with the trapped liquid during crystallization. Note lack of abrupt step between cores and rims. X-ray Fluorescence (XRF) images collected from the Australian Synchrotron using low energy $(7,050 \mathrm{eV}$ ) method (Barnes et al., 2020) Stacked false color (RGB) image of chromium concentration in red, manganese in green and calcium in blue. Mineral abbreviations: cpx, clinopyroxene; ol, olivine; opx, orthopyroxene; pl, plagioclase.

The Wanka Wanka Dyke (Figures 9A, 10C,D) is a small $(150 \mathrm{~m}$ wide and $15 \mathrm{~km}$ long) zoned dyke with an ultramafic core and mafic margin and is considered to likely represent part of the feeder system of the Giles Complex layered intrusions in central Australia. Both the clinopyroxene and orthopyroxene grains (Figure 9B) exhibit a diffuse reduction in the $\mathrm{Cr}$ concentration, then a sudden return to original $\mathrm{Cr}$ 
Barren/unmineralised intrusions

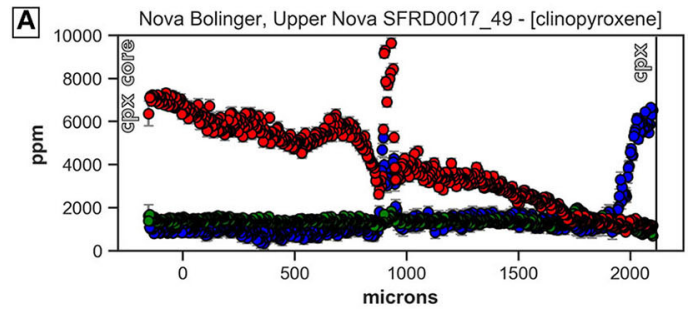

B

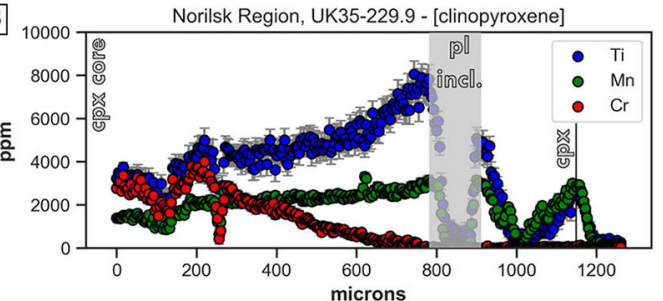

C

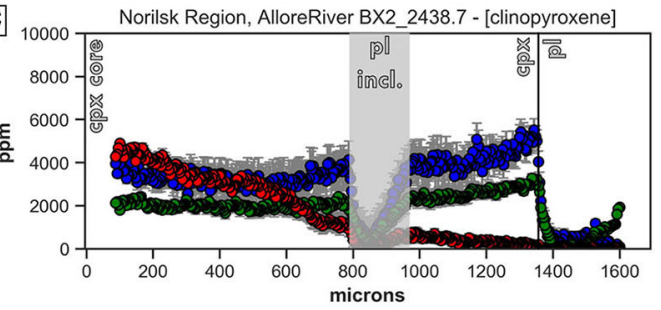

D

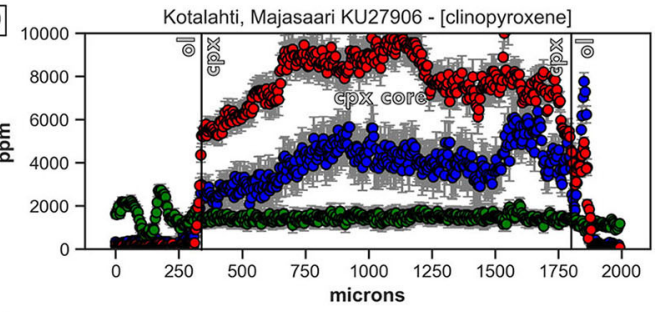

E

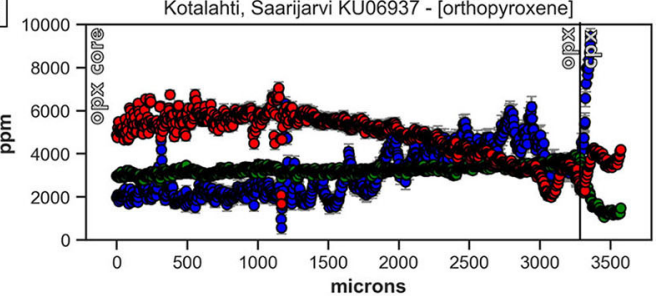

F

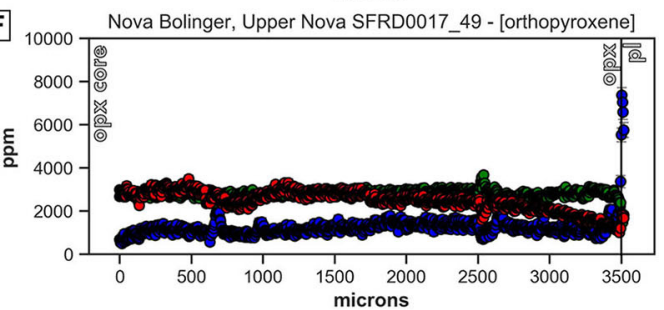

FIGURE 8 | Traverses across clinopyroxene and orthopyroxene from core to rim in barren and unmineralized intrusions. (A) Clinopyroxene from Upper Nova intrusion (Figure 7E), (B) clinopyroxene from Chernogorsk, Norilsk Region

(Figure 7F), (C) clinopyroxene from the Allore River intrusion, Norilsk Region (Figure 7G), (D) a traverse from clinopyroxene edge to edge through core from the Majassaari intrusion of the Kotalahti Ni Belt (Figure 7A), and (E) core to rim traverse through an orthopyroxene of the Saarijarvi intrusions, Kotalahti Ni-belt (Figure 7C). (F) An orthopyroxene from Upper Nova intrusion (Figure 7E). concentrations with an embayed boundary which is repeated (in this case 3 times; Figure 10C). This is an example of magma recharge into a mafic system during pyroxene growth which is discussed further below. This intrusion contains no known sulfide accumulations.

The Jimberlana Dyke contains minor disseminated sulfides in orthocumulate layers close to its margins but no economic concentrations. The cumulus orthopyroxenes within the Jimberlana intrusion show extremely faint sector zoning while the clinopyroxene oikocrysts are dominated by faint normal zoning (Figures 9D, 10E,F). The Ora Banda Sill contains traces of centrally-disposed platinum group element enriched sulfides within orthopyroxenites. In the Ora Banda Sill, both pyroxenes show normal zonation toward the rims (Figures 9E,F, 10G) with the exception of the orthopyroxene chadacrysts, within the core of the clinopyroxene oikocrysts, which are smaller and do not display normal zonation. The Ngunala (Caroline) intrusion has homogenous levels of $\mathrm{Cr}$ throughout all the orthopyroxene and clinopyroxene grains (Figures 10A,B).

\section{DISCUSSION}

A common feature of the pyroxenes in the mineralized intrusions is abrupt normal zonation, whereby chromium rich cores zone abruptly to chromium poor rims (Figures 3A-D,G), whereas the unmineralized intrusions are dominated by smooth normal zonation. The most plausible explanation for abrupt zonation is that the Cr-enriched core represents open-system cumulus growth at the liquidus temperature of the magma, where the growing crystal remains in contact with flowing magma in a chamber or conduit, while the rim represents diffusion-limited post-cumulus growth from trapped intercumulus liquid within a crystal mush. In this situation, the trapped liquid becomes progressively depleted in $\mathrm{Cr}$ due to the high compatibility of $\mathrm{Cr}$ in pyroxenes.

Samples from Aguablanca, Spain (Figure 3F) display "reverse zoned" clinopyroxenes, with chromium poor cores, a chromium rich mantle then a chromium poor rim. Samples from Huangshanxi, China (Figure 3E) display "reversed rimmed" orthopyroxenes where the concentration of chromium is high in the core, surrounded by a mantle of low concentrations of chromium and returning to high concentrations at the rims. These patterns cannot be explained by a simple two-stage history (cumulus followed by postcumulus) and imply some kind of multi-stage reworking in a dynamic crystallization environment.

In general, the value for $\mathrm{Cr}$ within orthopyroxene cores in the mineralized intrusions is fairly consistent $(6,800 \pm 1,700$ $\mathrm{ppm})$, probably reflecting equilibrium with magma saturated in chromite (Barnes et al., 2016b). The unmineralized intrusions are variable, ranging from clinopyroxene cores with values as high as 7,900 $\pm 1300 \mathrm{ppm}$ (Majasaari, Kotalahti) to $2,000 \pm 100 \mathrm{ppm}$ (Ngunala-Caroline). In the same sample, the concentrations are similar between both clinopyroxene and orthopyroxene. This suggests the partition coefficient 


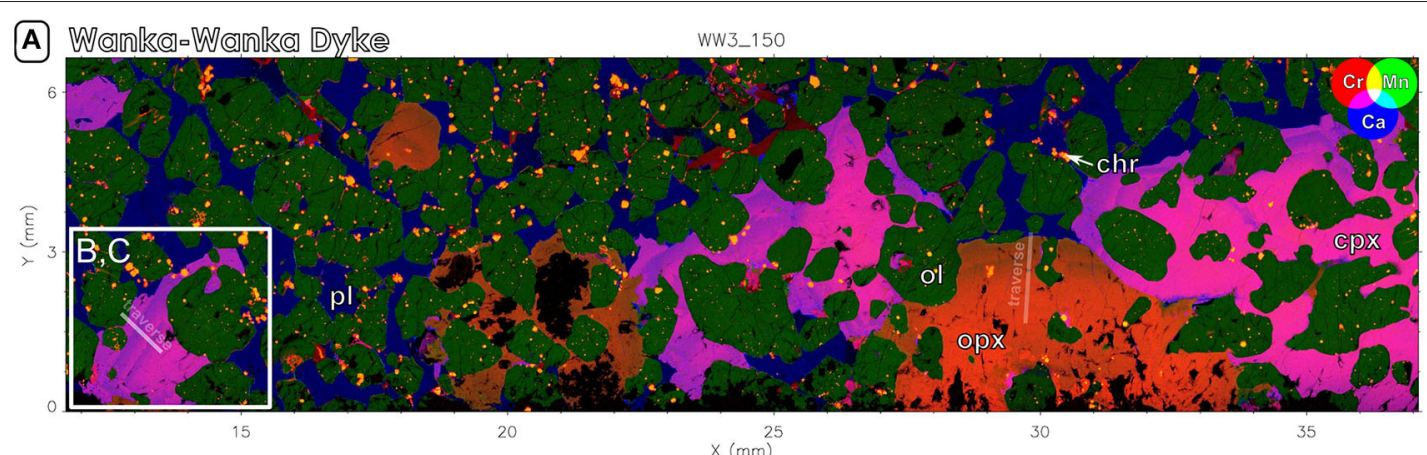

(B)

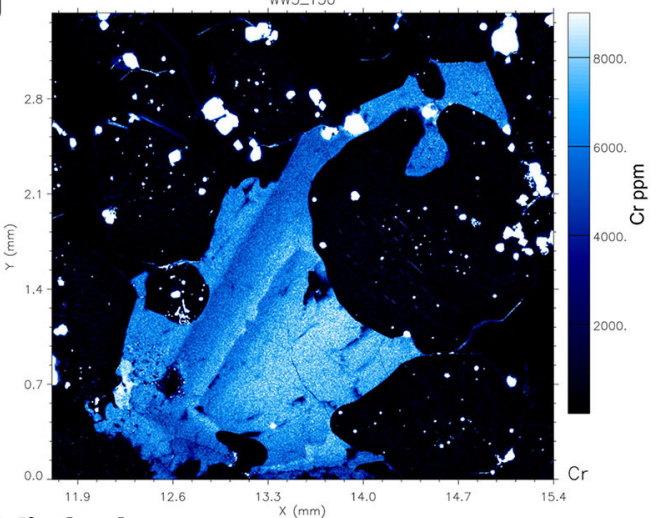

(C)

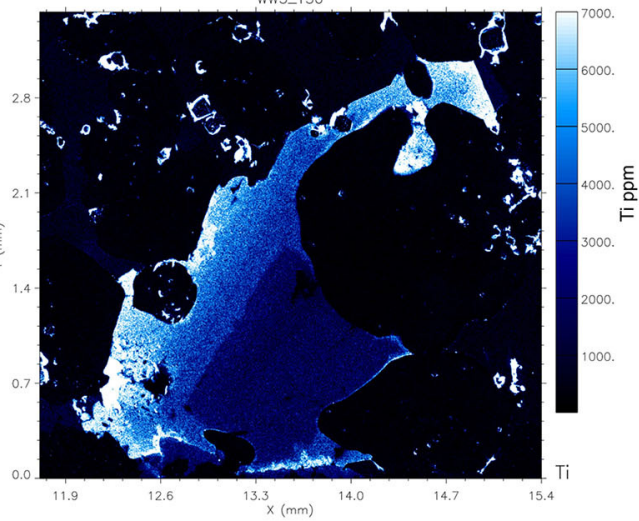

(D) dimberl@n@

A65
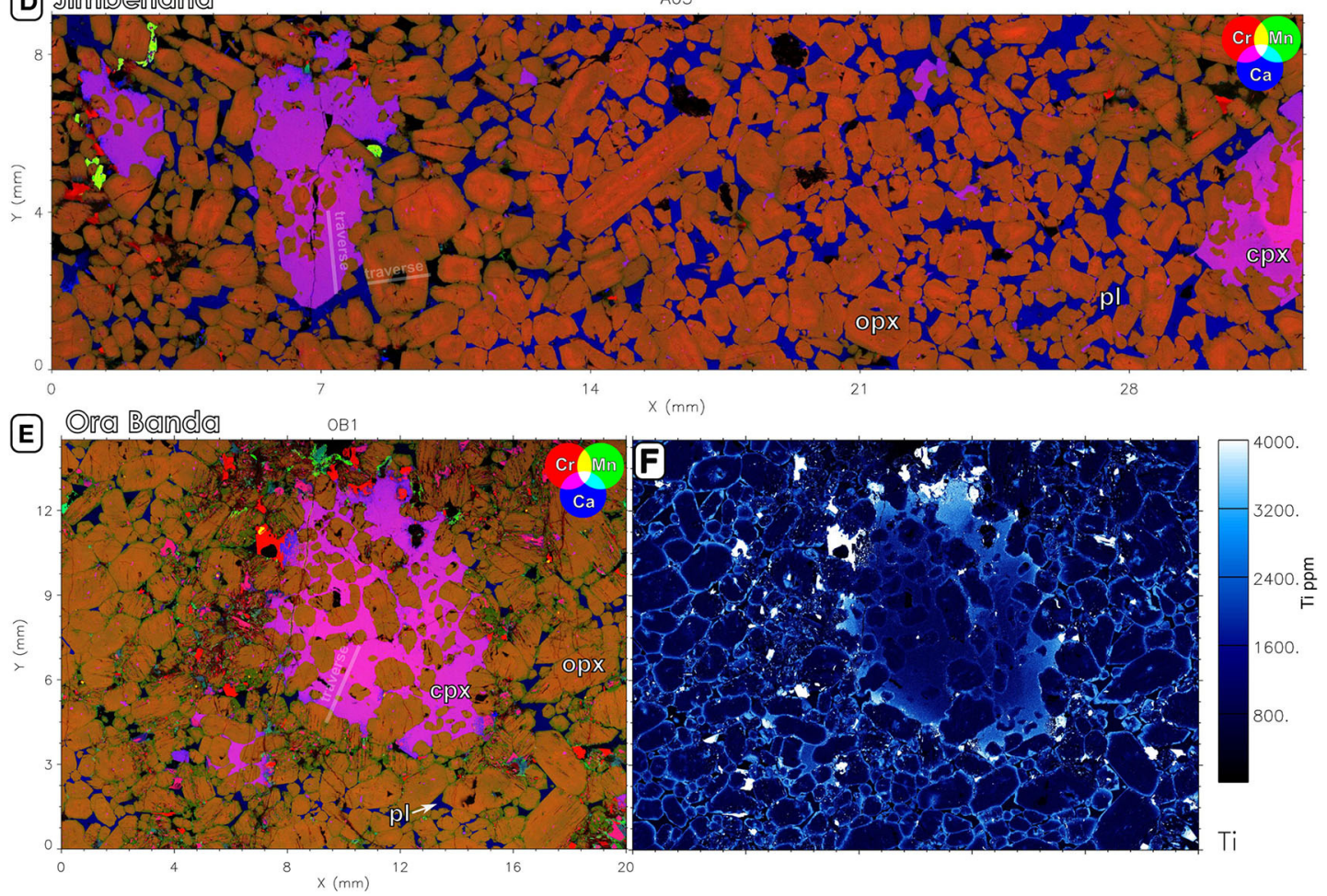

FIGURE 9 | Pyroxene textures in mafic intrusions that are not associated with mineralization (other than localized minor disseminations). (A) Wanka Wanka Dyke with inset of (B,C). (B) Cr map of clinopyroxene; oscillatory zoning. (C) Ti map of clinopyroxene; normal zoning. (D) Jimberlana; large clinopyroxene oikocryst that contains small orthopyroxene chadacrysts in a matrix of weakly sector zoned orthopyroxene and plagioclase. (E) Ora Banda; large clinopyroxene oikocrysts with orthopyroxene chadacrysts in an orthopyroxene and plagioclase matrix. (F) Normal zonation in Ora Banda pyroxene with an increased in incompatible elements (such as Ti) in the rims. X-ray Fluorescence (XRF) images collected from the Australian Synchrotron using low energy (7,050 eV) method (Barnes et al., 2020) Stacked false color (RGB) image of chromium concentration in red, manganese in green and calcium in blue. Mineral abbreviations: cpx, clinopyroxene; ol, olivine; opx, orthopyroxene; pl, plagioclase. 


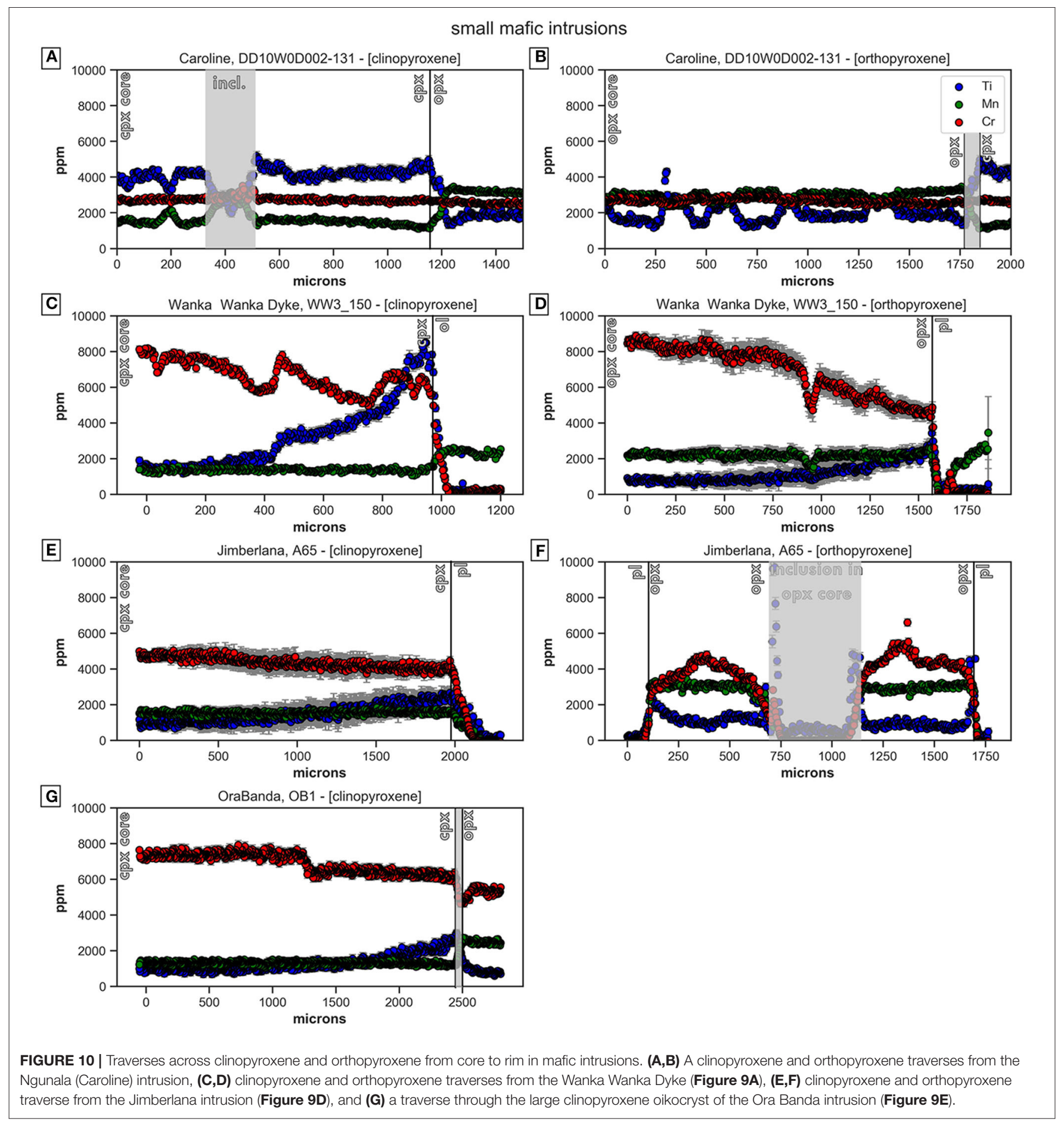

for chromium is similar in both phases, however, as sector zoning is visible, the partitioning is slightly different within each sector.

We compared the concentration of adjacent sector zones in orthopyroxene grains in a number of samples and calculated the $\mathrm{Cr}$ enrichment factor (high concentration over low concentration) between the sectors. The enrichment factors in the ore grade samples range from 1.1 to 1.8 with an average $(n=83)$ of $1.6 \pm 0.2$ times enrichment between the sectors (Figure 11). The unmineralized intrusions (Jimberlana and Kotalahti) have enrichment factors between sectors within orthopyroxene grains of $1.4 \pm 0.2(n=34)$ which is within a standard deviation of the mineralized intrusions. The average enrichment factor for $\mathrm{Cr}$ measured in these intrusive orthopyroxene grains is similar to those measured between sectors 


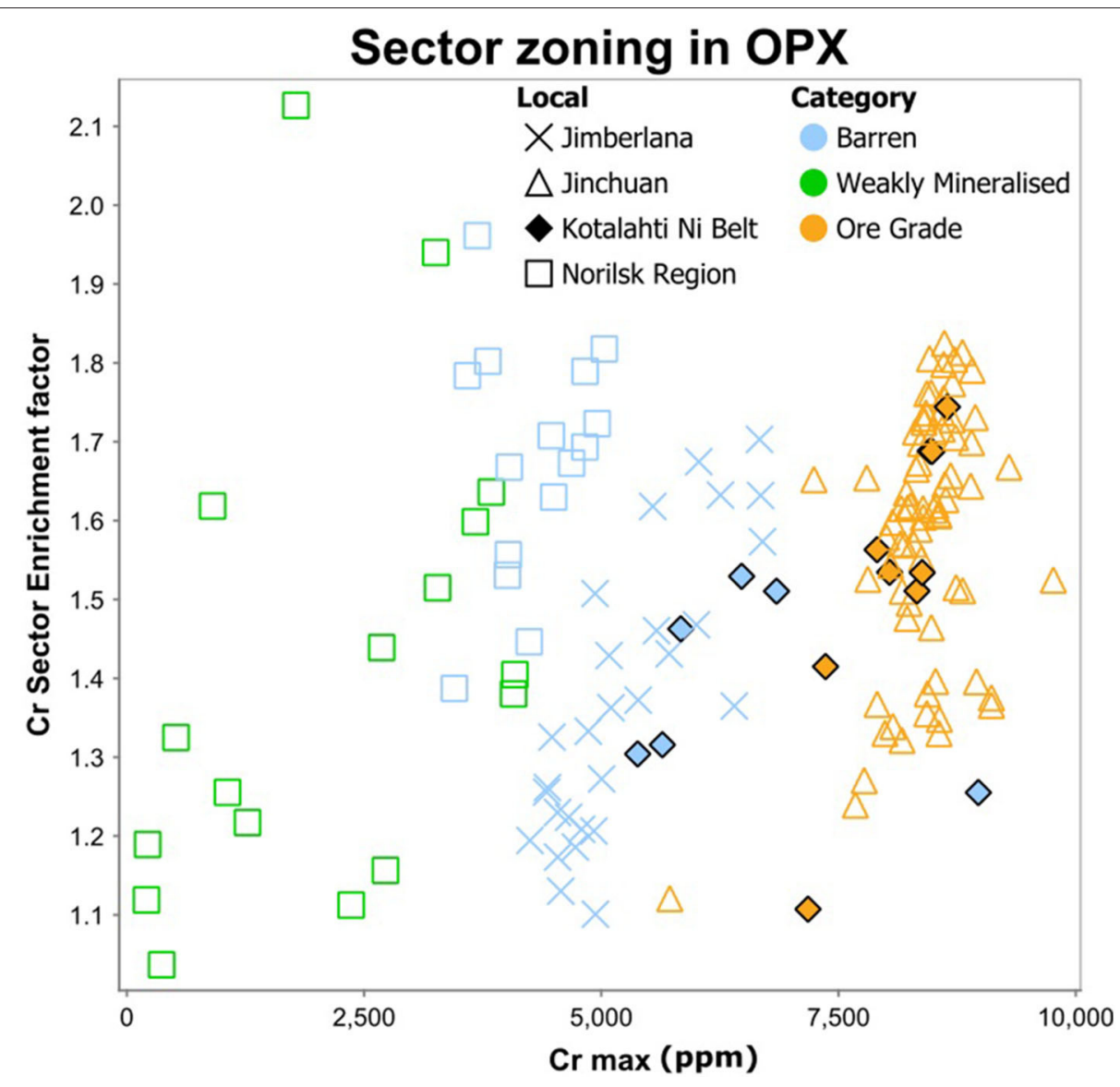

FIGURE 11 | The sector zone enrichment factor for $\mathrm{Cr}$ (high concentration sector over low concentration sector) for orthopyroxene (opx) in samples taken from the Australian Synchrotron $\mu$ XRF maps. Average for each category is Barren $=1.4$, weakly mineralized $=1.5$, ore grade $=1.6$.

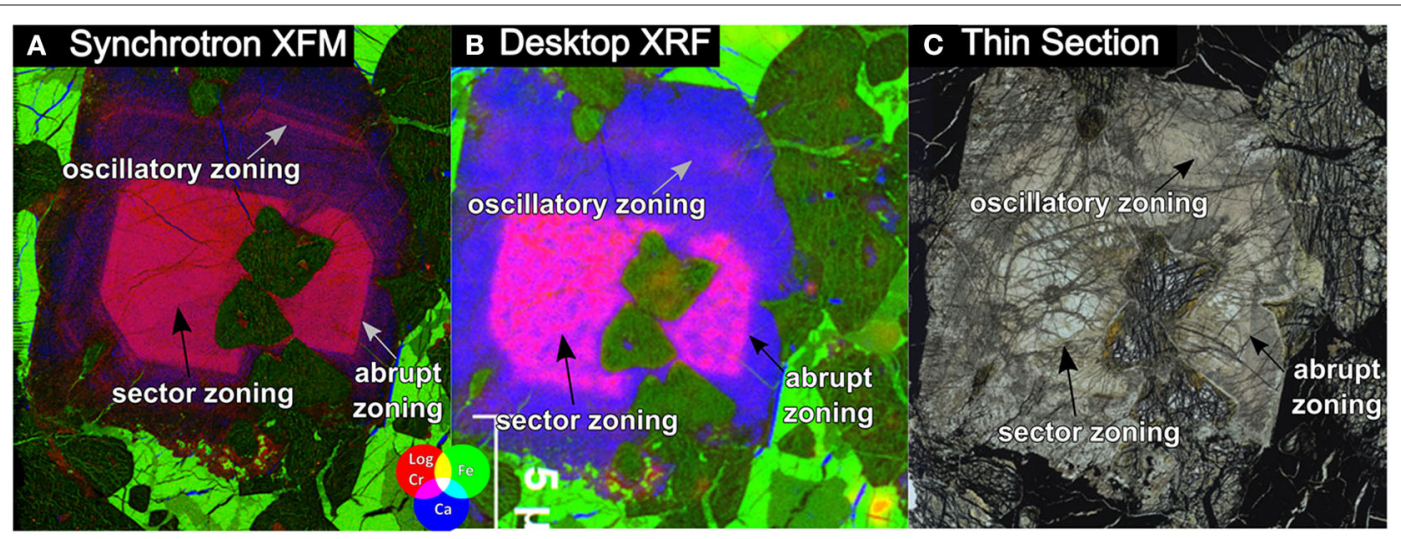

FIGURE 12 | Sample KU30024 imaged by (A) $\mu$ XRF on the Australian synchrotron, (B) a Bruker desktop microbeam XRF mapper-M4 Tornado TM , (C) and plane polarized light image of the thin section. The abrupt zoning can be observed very well with a desktop XRF system and can sometimes be distinguished in thin section. The sector zoning is also visible in thin section.

in volcanic clinopyroxenes (1.4 times) in Ubide et al. (2019).

Partitioning of trace elements is dependent on many extrinsic variables, such as pressure, temperature and melt composition (Ewart et al., 1973; Barnes, 1986; Hart and Dunn, 1993;
Lundstrom et al., 1998; Frei et al., 2009; Schoneveld, 2017) and the partitioning between the sectors in pyroxenes may also be dependent on these variables. Few experimental studies have been conducted looking at the partitioning between sectors in minerals (Kouchi et al., 1983; Schwandt and McKay, 2006) but 


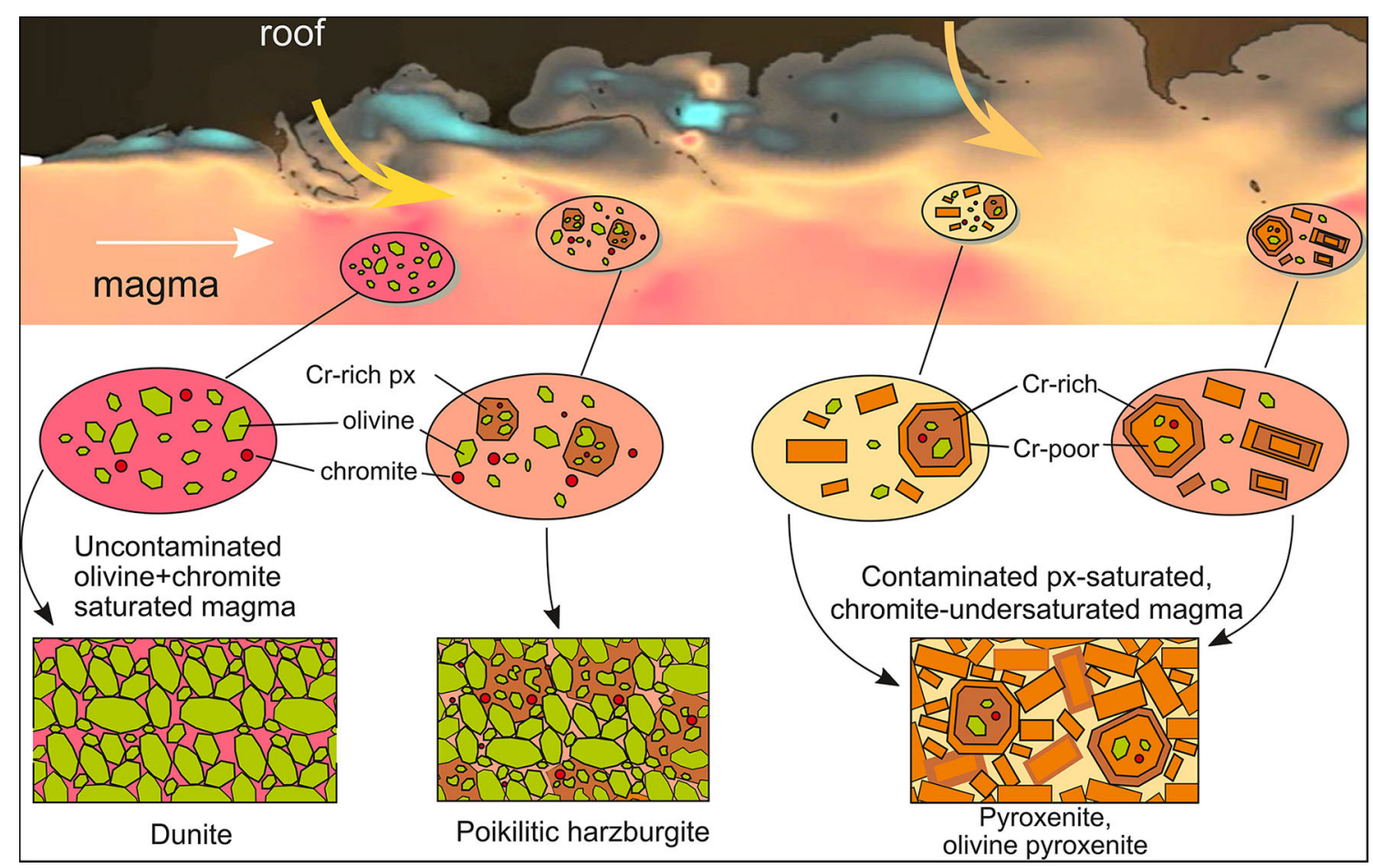

FIGURE 13 | The flowing magma assimilates the surrounding material, causing short-range transient fluctuations in composition, silica activity and redox state in poorly mixed magma. This allows for complex zoning of the mineral phases. sulfide mineralization can occur due to the assimilation of country rocks, therefore these zoning patterns can indicate high magma volumes required to form sulfide mineralization. Diagram modified from Barnes et al. (2016b).

this partitioning may prove to provide insights into the magmatic histories. The main problem with using partition coefficients for magma history determinations is not being certain of the melt composition, which is usually not amenable to direct sampling. If extrinsic variables can be determined from partitioning between sectors in a single crystal, the melt becomes less relevant.

The Wanka Wanka dyke contains a good example of a clinopyroxene grain recording the extrinsic change of the system (Figure 9B). The $\mathrm{Cr}$ concentration profile exhibits a sawtooth pattern (Figure 10C) with a gradual concentration decrease followed by a rapid and significant increase after an embayed boundary (Figure 9B). This embayment, along with the oscillation in $\mathrm{Cr}$ content is a strong indication of dissolution due to magma recharge (Ubide and Kamber, 2018). The $\mathrm{Ti}$ concentration in this sample displays normal zoning, with an increase in $\mathrm{Ti}$ concentration after the first magma recharge (Figure 9C). As titanium can be an order of magnitude less compatible in clinopyroxenes than chromium (Bédard, 2014; Schoneveld, 2017), it does not record the small recharge in magma chemistry but does record the distinct change in chemistry between cumulus and post cumulus growth. Interestingly, the sawtooth-patterned clinopyroxene grain here appears to be an oikocryst, as discussed further in the next section.

Oscillatory zoning of $\mathrm{Cr}$ can also be observed throughout the mineralized intrusions, although these oscillations are usually at much finer scale (Figure 3). Examined at high spatial resolution
(Figure 3A), these oscillations in chemistry can be observed in both the cores and rims of ortho- and of clinopyroxenes (Figure 4), although the variations are usually on the scale of 10-100 ppm. In contrast, the increase in $\mathrm{Cr}$ concentration in the clinopyroxene grains of the Wanka Wanka sample reaches $\sim 2,000 \mathrm{ppm}$. Oscillatory zoning is thought to occur in clinopyroxenes that grow moderately rapidly $\left[10^{-11}\right.$ and $10^{-13}$ $\mathrm{m} / \mathrm{s}$; Fowler and Shore (1996)] which suggests the clinopyroxene grain in the Rytky intrusion of Kotalahti (Figure 3A) took anywhere from $\sim 10$ to 1,000 years to grow the outer, oscillated rims. If we could refine growth speed calculations further, this would be a great asset in determining the formation timescale of the "long lived" intrusions.

\section{FORMATION OF OIKOCRYSTS}

Pyroxene oikocrysts are common in mafic intrusions both small and large (Wager et al., 1960; Wager and Brown, 1969; Barnes et al., 2016b, 2019b; Mao et al., 2019) creating what is known as poikilitic textures (Figure 6). These pyroxene oikocrysts can be multi-centimeter in scale with inclusions (chadacrysts) of smaller phases (usually olivine, pyroxene or chromite). All of the intrusion types (mineralized, unmineralized, and those not associated with mineralization) can display poikilitic textures (Figures 6, 7A, 9E). These grains characteristically trap the early cumulus phases which allows us to analyse the evolution of the chemistry of the system as well as the evolution of the 
texture. The small chadacrysts within pyroxene oikocrysts can either represent the first stage of nucleation or remnant grains following peritectic dissolution. By performing detailed crystal size distribution (CSD) analysis we are able to make some inferences of the formation of the systems (Berger et al., 2011; Kaufmann et al., 2018; Mao et al., 2018; Schoneveld et al., 2020).

There are two main theories for the formation of oikocrysts in these systems (Kaufmann et al., 2018): (1) the postcumulus model: formation in-situ in the cumulate pile from the intercumulus trapped liquid (Wager et al., 1960); (2) The cumulus model: growth during the formation of the cumulate (Campbell, 1968; Mathison, 1987; Tegner and Wilson, 1995; Barnes et al., 2016b), with the poikilitic texture arising from differential nucleation and growth rates of the poikilitic and enclosed (chadacryst) phases (McBirney and Noyes, 1979).

By using the Cr-zoning we have outlined in this manuscript, we can make further inferences on the formation of these textures. The smooth normal zonation that characterizes the unmineralized intrusions (Figure 7A) would be aligned with the post-cumulate theory of formation, with the steady decrease in chromium indicating a closed system where earlyformed cumulus phases are undergoing reaction with trapped intercumulus liquid. The sector zoning and oscillations in the oikocrysts in mineralized intrusions (Figure 6) represent rapid growth in a still actively forming and crystallizing cumulate without this steady depletion in $\mathrm{Cr}$ from the postcumulate reactions.

We can use the zonation of different elements to infer combinations of cumulate and post-cumulate growth such as those outlined from the Wanka Wanka Dyke (Figure 9) where $\mathrm{Cr}$ contents suggest there was a magma recharge event during oikocryst growth. This may have been possible by (1) growth from intercumulus liquid within a crystal mush in the presence of advecting or convecting intercumulus liquid communicating with the main magma source (Kerr and Tait, 1985, 1986); (2) rapid crescumulate growth due to supersaturation in a boundary layer at the mush-magma interface (Campbell, 1968; McBirney and Noyes, 1979; Mathison, 1987; Godel et al., 2013; Barnes et al., 2016b, 2018; Mao et al., 2018), or (3) growth within the mush by peritectic reaction between cumulus crystals and upward-migrating evolved liquid derived from crystal mush beneath (Kaufmann et al., 2018). Given that the Wangka Wankga sample represents a cumulate from the center of a relatively small ( $\sim 100 \mathrm{~m}$ wide) dike, the first and third interpretations are unlikely, and we prefer the second.

\section{CR ZONATION IN PYROXENES AS AN EXPLORATION TOOL}

Commonly, economic $\mathrm{Ni}-\mathrm{Cu}$ sulfide deposits are found within a small proportion of the intrusions within a given magmatic province. Excellent examples of this are the Norilsk-Talnakh region of Siberia (Naldrett, 2004) or the Halls Creek Orogen of Western Australia (Mole et al., 2018; Le Vaillant et al., 2020). Our results suggest that, while they might not be strictly diagnostic, zoning patterns in pyroxenes might be useful indicators (along with other factors) for ranking relative prospectivity of maficultramafic intrusions where limited sampling is available, for example at the early stages of a regional exploration program. Our results are primarily based on synchrotron data, not readily available in an exploration context. However, most of the important features can be recognized with lab-based microbeam XRF mapping (Figure 12).

Desktop XRF mappers are becoming more affordable and more widely utilized in exploration. The technology is becoming faster to use and cheaper to acquire with the data obtained from these XRF mappers giving elemental and textural data on minimally prepared drill core samples. With some geological knowledge, this data can readily be transformed into to mineralogical information. Sample preparation requires only a flat saw-cut surface, which is a significant reduction in time when compared to the creation of thin section or drilled and polished rounds/mounts for other microanalytical techniques. Although these technologies may never replace detailed petrography and electron-beam microanalysis, they are a useful intermediate step to ensure sampling of representative or key areas for microanalysis, to give context to these analysis (Barnes et al., 2017b; Pearce et al., 2017), and to provide valable textural and mineralogical evidence on processes operating at $\mathrm{cm}$ or $\mathrm{dm}$ scales not recognizable in thin sections (e.g., Barnes et al., 2020).

Comparing the same sample (KU30024) collected using both the Australian Synchrotron XRF and a desktop XRF, many of the features can be observed using both techniques. The important distinguishing features; poikilitic textures, abrupt zonation and sector zoning are visible using the desktop techniques. The zoning patterns observed in the unmineralized intrusions are of much lower concentrations and are only readily visible using complex, low energy and higher resolution techniques using the Australian Synchrotron. Therefore, the unmineralized samples do not show any of these zonation patterns when examined with the desktop XRF mapping techniques.

\section{Limitations}

Thus, far we have mostly investigated samples from within the sulfide rich zone of the mineralized intrusion. Future research is needed to systematically investigate how far these signals propagate through the magma conduit away from the sulfide. Quantification of the limits on growth rate imposed by preservation of sector and other zoning types will be vital in extracting more information from these intriguing textures.

\section{CONCLUSIONS}

In summary, we have observed a suite of possible zoning patterns in pyroxenes that may be observed when examining mafic intrusions.

1. Abrupt zoning $(\mathrm{Cr})-\mathrm{a}$ zone of low $\mathrm{Cr}$ concentration around a $\mathrm{Cr}$ rich $(\sim>5,000 \mathrm{ppm})$ core, with a steep concentration gradient defining the core-rim boundary;

2. Sector zoning $(\mathrm{Cr})$-hour-glass style of zonation in the core of pyroxene grains and/or; 
3. Cumulate poikilitic pyroxenes-large pyroxene grains enclosing smaller olivine, pyroxene or chromite grains, commonly showing abrupt zoning toward sharply Cr-depleted rims.

To date, our studies indicate that sector zoning in pyroxenes, both clearly cumulus and poikilitic, is almost ubiquitous in small intrusions with relatively rapid cooling rates (but much less evident in large intrusions such as the Bushveld Complex). Abrupt zoning is most commonly observed in mineralized intrusions while smooth gradual zoning toward Cr-poor rims is more characteristic of unmineralized bodies.

The presence of sector zoning within oikocryst cores is noted in several localities, both mineralized (e.g., Norilsk-Talnakh) and unmineralized (Majasaari) and is of particular interest from the point of view of the origin of poikilitic textures. It tends to favor a model for simultaneous growth of both oikocryst and chadacryst phases with the poikilitic phase growing faster from fewer nucleation sites.

One particular combination of characteristics has so far only been observed within mineralized intrusions: poikilitic pyroxenes (particularly orthopyroxene) with abrupt, in some cases oscillatory, zoning which have euhedral Cr-rich cores containing olivine inclusions. Following Barnes et al. (2016b) we suggest that this combination of features arises from reactive transport of olivine and orthopyroxene grains within variably contaminated magma in dynamic conduit systems (Figure 13). Orthopyroxene grows as a result of peritectic reaction between suspended olivine and locally Si-saturated contaminated magma. Where the magma is initially chromitesaturated, the high $\mathrm{Cr}$ content of the growing orthopyroxene cores is buffered by equilibrium with chromite. Such dynamic flow conditions coupled with the necessity of assimilation of externally derived sulfur (Ripley and Li, 2013; Barnes et al., 2016a) are essential to the origin of magmatic Ni-Cu-PGE sulfide ores in conduit settings.

As revealed by XRF-based mapping technique, it appears that zoning in pyroxenes may actually be as widespread and complex as the more familiar zoning patterns in plagioclases and zircons.

\section{REFERENCES}

Barnes, S., Le Vaillant, M., Godel, B., and Lesher, M. (2019a). Droplets and bubbles: solidification of sulphide-rich vapour-saturated orthocumulates in the Norilsk-Talnakh Ni-Cu-PGE ore-bearing intrusions. J. Petrol. 60, 269-300. doi: 10.1093/petrology/egy114

Barnes, S. J. (1986). The distribution of chromium among orthopyroxene, spinel and silicate liquid at atmospheric pressure. Geochim. Cosmochim. Acta 50, 1889-1909. doi: 10.1016/0016-7037(86)90246-2

Barnes, S. J., Cruden, A. R., Arndt, N., and Saumur, B. M. (2016a). The mineral system approach applied to magmatic Ni-Cu-PGE sulphide deposits. Ore Geol. Rev. 76, 296-316. doi: 10.1016/j.oregeorev.2015.06.012

Barnes, S. J., Holwell, D. A., and Le Vaillant, M. (2017a). Magmatic sulfide ore deposits. Elements 13, 91-97. doi: 10.2113/gselements.13.2.89

Barnes, S. J., Mole, D. R., Hornsey, R., and Schoneveld, L. E. (2019b). Nickel-copper sulfide mineralization in the ntaka hill ultramafic complex, nachingwea region, tanzania. Econ. Geol. 114, 1135-1158. doi: 10.5382/econgeo.4677

\section{DATA AVAILABILITY STATEMENT}

The datasets generated for this study are available on request to the corresponding author.

\section{AUTHOR CONTRIBUTIONS}

LS and SB wrote and edited the manuscript as well as collected and analyzed the data and created all the figures. HM, VT, K-YW, and Y-JM provided samples and expertise on their mineral deposits. ML, DP, and VT assisted in collecting and analyzing the data. All authors contributed to the article and approved the submitted version.

\section{ACKNOWLEDGMENTS}

This research is a collection of data obtained over the last 5 years as small parts of experiments 8941, 8965, 10023, 11667, and 14304 and as the focus of experiments 13405 and 15166 on the X-ray fluorescence microscopy beamline at the Australian Synchrotron, part of ANSTO. We would like to thank everyone who collected, lent, and prepared the samples used in this study as well as all those who helped with their technical expertise to enable the researchers to collect this data. In particular, we thank IGO Ltd. for access to the Nova-Bollinger deposit. Teresa Ubide is thanked for suggesting this manuscript be submitted to this research topic and her assistance with experiment 15,166 on the Australian Synchrotron. This manuscript benefitted from suggestions from Belinda Godel and Siyu Hu before submission. The manuscript was also improved by two reviewers and Catherine Annen. MP is thanked for the editorial handling of this manuscript.

\section{SUPPLEMENTARY MATERIAL}

The Supplementary Material for this article can be found online at: https://www.frontiersin.org/articles/10.3389/feart. 2020.00256/full\#supplementary-material

Barnes, S. J., Mole, D. R., Le Vaillant, M., Campbell, M., Verrall, M., Roberts, M., et al. (2016b). Poikilitic textures, heteradcumulates and zoned orthopyroxenes in the Ntaka Ultramafic Complex, Tanzania: implications for crystallisation mechanisms of oikocrysts. J. Petrol. 57, 1171-1198. doi: 10.1093/petrology/egw036

Barnes, S. J., Mungall, J. E., Le Vaillant, M., Godel, B., Lesher, C. M., Holwell, D., et al. (2017b). Sulfide-silicate textures in magmatic Ni-Cu-PGE sulfide ore deposits: disseminated and net-textured ores. Am. Mineral. 102, 473-506. doi: 10.2138/am-2017-5754

Barnes, S. J., Paterson, D., Ubide, T., Schoneveld, L., Ryan, C., and Le Vaillant, M. (2020). Imaging trace-element zoning in pyroxenes using synchrotron XRF mapping with the Maia detector array: benefit of low-incident energy. Am. Mineral. 105, 136-140. doi: 10.2138/am-2020-7228

Barnes, S. J., Piña, R., and Le Vaillant, M. (2018). Textural development in sulfide-matrix ore breccias in the Aguablanca Ni-Cu deposit, Spain, revealed by X-ray fluorescence microscopy. Ore Geol. Rev. 95, 849-862. doi: 10.1016/j.oregeorev.2018.03.004 
Barnes, S. J., and Robertson, J. C. (2019). Time scales and length scales in magma flow pathways and the origin of magmatic Ni-Cu-PGE ore deposits. Geosci. Front. 10, 77-87. doi: 10.1016/j.gsf.2018.02.006

Barnes, S. J., Taranovic, V., Miller, J. M., Boyce, G., and Beresford, S. W. (in press). Sulfide emplacement and migration in the Nova-Bollinger $\mathrm{Ni}-\mathrm{Cu}-\mathrm{Co}$ deposit, Albany-Fraser Orogen, Western Australia. Econ. Geol.

Bédard, J. H. (2014). Parameterizations of calcic clinopyroxene-Melt trace element partition coefficients. Geochem. Geophys. Geosyst. 15, 303-336. doi: 10.1002/2013GC005112

Berger, A., Herwegh, M., Schwarz, J.-O., and Putlitz, B. (2011). Quantitative analysis of crystal/grain sizes and their distributions in 2D and 3D. J. Struct. Geol. 33, 1751-1763. doi: 10.1016/j.jsg.2011.07.002

Bernstein, S. (2006). In situ fractional crystallization of a mafic pluton: microanalytical study of a Palaeogene gabbronorite plug in East Greenland. Lithos 92, 222-237. doi: 10.1016/j.lithos.2006.03.034

Campbell, I. H. (1968). The origin of heteradcumulate and adcumulate textures in the Jimberlana Norite. Geol. Mag 105, 378-383. doi: $10.1017 /$ S0016756800054431

Chai, G., and Naldrett, A. J. (1992). The Jinchuan ultramafic intrusion: cumulate of a high-Mg basaltic magma. J. Petrol. 33, 277-304. doi: 10.1093/petrology/33.2.277

Cherniak, D. J., and Dimanov, A. (2010). Diffusion in pyroxene, mica and amphibole. Rev. Mineral. Geochem. 72, 641-690. doi: 10.2138/rmg.2010.72.14

Downes, M. J. (1974). Sector and oscillatory zoning in calcic augites from M. Etna, Sicily. Contrib. Mineral. Petrol. 47, 187-196. doi: 10.1007/BF00371538

Ewart, A., Bryan, W. B., and Gill, J. B. (1973). Mineralogy and Geochemistry of the Younger Volcanic Islands of Tonga, S.W. Pacific. J. Petrol. 14, 429-465. doi: 10.1093/petrology/14.3.429

Fowler, A. D., and Shore, M. (1996). Oscillatory zoning in minerals; a common phenomenon. Canad. Mineral. 34, 1111-1126.

Frei, D., Liebscher, A., Franz, G., Wunder, B., Klemme, S., and Blundy, J. (2009). Trace element partitioning between orthopyroxene and anhydrous silicate melt on the lherzolite solidus from 1.1 to $3.2 \mathrm{GPa}$ and 1,230 to $1,535^{\circ} \mathrm{C}$ in the model system Na2O-CaO-MgO-Al2O3-SiO2. Contribut. Mineral. Petrol. 157, 473-490. doi: 10.1007/s00410-008-0346-5

Godel, B. M., Barnes, S. J., Gurer, D., Austin, P., and Fiorentini, M. L. (2013). Chromite in komatiites: 3D morphologies with implications for crystallization mechanisms. Contribut. Mineral. Petrol. 165, 173-189. doi: 10.1007/s00410-012-0804-y

Hargraves, R. B., Hollister, L. S., and Otalora, G. (1970). Compositional zoning and its significance in pyroxenes from three coarse-grained lunar samples. Science 167, 631-633. doi: 10.1126/science.167.3918.631

Hart, S. R., and Dunn, T. (1993). Experimental cpx/melt partitioning of 24 trace elements. Contribut. Mineral. Petrol. 113, 1-8. doi: 10.1007/BF00320827

Hollister, L. S., and Gancarz, A. J. (1971). Compositional sector-zoning in clinopyroxene from the Narce area, Italy. Am. Mineral. 56, 959.

Hollister, L. S., Trzcienski, W. E. Jr., Hargraves, R. B., and Kulick, C. G. (1971). Petrogenetic significance of pyroxenes in two Apollo 12 samples. Geochim. Cosmochim. Acta 2, 529-557.

Irvine, T. N. (1982). Terminology for layered intrusions. J. Petrol. 23, 127-162. doi: 10.1093/petrology/23.2.127-a

Kaufmann, F., Vukmanovic, Z., Holness, M., and Hecht, L. (2018). Orthopyroxene oikocrysts in the MG1 chromitite layer of the Bushveld Complex: implications for cumulate formation and recrystallisation. Contribut. Mineral. Petrol. 173, 1-20. doi: 10.1007/s00410-018-1441-x

Keays, R. R., and Campbell, I. H. (1981). Precious metals in the Jimberlana Intrusion, Western Australia: implications for the genesis of platiniferous ores in layered intrusions. Econ. Geol. 76, 1118-1141. doi: 10.2113 /gsecongeo.76.5.1118

Kerr, R. C., and Tait, S. R. (1985). Convective exchange between pore fluid and an overling reservoir of dense fluid: a postcumulus process in layered intrusions. Earth Planet. Sci. Lett. 75, 147-156. doi: 10.1016/0012-821X(85)90097-4

Kerr, R. C., and Tait, S. R. (1986). Crystallisation and compositional convection in a porous medium with application to layered igneous intrusions. J. Geophys. Res. 91, 3591-3608. doi: 10.1029/JB091iB03p03591

Kirkham, R., Dunn, P., Kuczewski, A., Siddons, D., Dodanwela, R., Moorhead, G., et al. (2010). The Maia spectroscopy detector system: engineering for integrated pulse capture, low-latency scanning and real-time processing. Proc. Aust. Inst. Phys. 1234, 240-243. doi: 10.1063/1.3463181

Kouchi, A., Sugawara, Y., Kashima, K., and Sunagawa, I. (1983). Laboratory growth of sector zoned clinopyroxenes in the system CaMgSi2O6-CaTiAl2O6. Contribut. Mineral. Petrol. 83, 177-184. doi: 10.1007/BF00373091

Le Vaillant, M., Barnes, S. J., Mungall, J. E., and Mungall, E. L. (2017). Role of degassing of the Noril'sk nickel deposits in the Permian-Triassic mass extinction event. Proc. Natl. Acad. Sci. U.S.A. 114, 2485-2490. doi: $10.1073 /$ pnas. 1611086114

Le Vaillant, M., Barnes, S. J., Mole, D. R., Fiorentini, M. L., LaFlamme, C. K., Denyszyn, S., et al. (2020). Multidisciplinary study of a complex magmatic system: the Savannah Ni-Cu-Co Camp, Western Australia. Ore Geol. Rev. 117:102392. doi: 10.1016/j.oregeorev.2019.103292

Leung, I. S. (1974). Sector-zoned titanaugites morphology, crystal chemistry, and growth. Am. Mineral. 59, 127-138.

Li, X. H., Su, L., Chung, S. L., Li, Z. X., Liu, Y., Song, B., et al. (2005). Formation of the jinchuan ultramafic intrusion and the world's third largest ni-cu sulfide deposit: associated with the similar to 825 ma south china mantle plume? - Art. No. Q11004. Geochem. Geophys. Geosyst. 6:11004. doi: 10.1029/2005GC001006 Lofgren, G. E., Huss, G. R., and Wasserburg, G. J. (2006). An experimental study of trace-element partitioning between Ti-Al-clinopyroxene and melt: equilibrium and kinetic effects including sector zoning. Am. Mineral. 91, 1596-1606. doi: 10.2138/am.2006.2108

Lundstrom, C. C., Shaw, H. F., Ryerson, F. J., Williams, Q., and Gill, J. (1998). Crystal chemical control of clinopyroxene-melt partitioning in the Di-Ab-An system: implications for elemental fractionations in the depleted mantle. Geochim. Cosmochim. Acta 62, 2849-2862. doi: 10.1016/S0016-7037(98)00197-5

Mäkinen, J., and Makkonen, H. (2004). Petrology and structure of the Palaeoproterozoic (1.9 Ga) Rytky nickel sulphide deposit, Central Finland: a comparison with the Kotalahti nickel deposit. Intern. J. Geol. Mineral. Geochem. Mineral Deposits 39, 405-421. doi: 10.1007/s00126-004-0413-4

Makkonen, H., and Mursu, J. (2004). Tutkimustyöselostus Pielaveden Kunnassa Valtausalueilla Saarela 1 ja 2 (kaiv.rek.nrot 7294/1 ja 7572/1) Suoritetuista Nikkelimalmitutkimuksista Vuosina 1999-2003. Geological Survey of Finland, archive report M06/3314/2004/1/10

Makkonen, H. V. (1996). 1.9 Ga tholeiitic magmatism and related Ni-Cu deposition in the Juva area, SE Finland. Geol. Survey Finland Bull. 386, 101.

Makkonen, H. V. (2015). "Nickel deposits of the $1.88 \mathrm{Ga}$ kotalahti and vammala belts," in Mineral Deposits of Finland, eds W. D. Maier, R. Lahtinen and H. O' Brien (Elsevier), 253-287. doi: 10.1016/B978-0-12-410438-9. 00010-8

Makkonen, H. V., Halkoaho, T., Konnunaho, J., Rasilainen, K., Kontinen, A., and Eilu, P. (2017). Ni-(Cu-PGE) deposits in Finland - Geology and exploration potential. Ore Geol. Rev. 90, 667-696. doi: 10.1016/j.oregeorev.2017. 06.008

Mao, Y.-J., Barnes, S. J., Qin, K.-Z., Tang, D., Martin, L., Su, B., et al. (2019). Rapid orthopyroxene growth induced by silica assimilation: constraints from sectorzoned orthopyroxene, olivine oxygen isotopes and trace element variations in the Huangshanxi Ni-Cu deposit, Northwest China. Contribut. Mineral. Petrol. 174, 33. doi: 10.1007/s00410-019-1574-6

Mao, Y.-J., Barnes, S. J., Duan, J., Qin, K.-Z., Godel, B. M., and Jiao, J. (2018). Morphology and particle size distribution of olivines and sulphides in the Jinchuan Ni-Cu sulphide deposit: evidence for sulphide percolation in a crystal mush. J. Petrol. 59, 1701-1730. doi: 10.1093/petrology/egy077

Mathison, C. I. (1987). Pyroxene oikocrysts in troctolitic cumulates - evidence for supercooled crystallisation and postcumulus modification. Contribut. Mineral. Petrol. 97, 228-236. doi: 10.1007/BF00371242

McBirney, A. R., and Noyes, R. M. (1979). Crystallization and layering in the Skaergaard Intrusion. J. Petrol. 20, 487-554. doi: 10.1093/petrology/20.3.487

Mole, D. R., Barnes, S. J., Taylor, R. J. M., Kinny, P. D., and Fritz, H. (2018). A relic of the Mozambique Ocean in south-east Tanzania. Precambrian Res. 305, 386-426. doi: 10.1016/j.precamres.2017.10.009

Naldrett, A. J. (2004). Magmatic Sulfide Deposits: Geology, Geochemistry and Exploration. Heidelberg: Springer.

Pearce, M. A., Godel, B. M., Fisher, L. A., Schoneveld, L. E., Cleverly, J. S., Oliver, N. H. S., et al. (2017). Microscale data to macroscale processes: a review of 
microcharacterization applied to mineral systems. Geol. Soc. London Special Publicat. 453:SP453.3. doi: 10.1144/SP453.3

Ripley, E. M., and Li, C. (2011). "A review of conduit-related ni-cu-(pge) sulfide mineralization at the voisey's bay deposit, labrador, and the eagle deposit, northern michigan," in Magmatic Ni-Cu and PGE Deposits: Geology, Geochemistry and Genesis. Reviews in Economic Geology, Vol. 17, eds C. Li and E. M. Ripley (Littleton: Society of Economic Geologists), 181-197.

Ripley, E. M., and Li, C. (2013). Sulfide saturation in mafic magmas: is external sulfur required for magmatic Ni-Cu-(PGE) ore genesis? Econ. Geol. 108, 45-58. doi: 10.2113/econgeo.108.1.45

Ryan, C. G. (2000). Quantitative trace element imaging using pixe and the nuclear microprobe. J. Imaging Syst. Technol. 11, 219-230. doi: 10.1002/ima.1007

Ryan, C. G., Siddons, D. P., Kirkham, R., Li, Z. Y., de Jonge, M. D., Paterson, D. J., et al. (2014). Maia X-ray fluorescence imaging: Capturing detail in complex natural samples. J. Phys. Conf. Ser. 499:012002.

Schoneveld, L. E. (2017). Partitioning of trace elements between plagioclase, clinopyroxene and melt (Doctor of Philosophy). The Australian National University.

Schoneveld, L. E., Barnes, S. J., Williams, M., Le Vaillant, M., and Paterson, D. (2020). Silicate and oxide mineral chemistry and textures of the Norilsk-Talnakh Ni-Cu-PGE ore-bearing intrusions. Econ. Geol. doi: 10.5382 /econgeo. 4747

Schwandt, C. S., and McKay, G. A. (2006). Minor- and trace-element sector zoning in synthetic enstatite. Am. Mineral. 91, 1607-1615. doi: 10.2138/am.2006.2093

Song, X. Y., Danyushevsky, L. V., Keays, R. R., Chen, L.-M., and Wang, Y.-S. (2012). Structural, lithological, and geochemical constraints on the dynamic magma plumbing system of the Jinchuan Ni-Cu sulfide deposit, NW China. Mineral. Dep. 47, 277-297. doi: 10.1007/s00126-011-0370-7

Tegner, C., and Wilson, J. R. (1995). Textures in a poikilitic olivine gabbro cumulate: evidence for supercooling. Mineral. Petrol. 54, 161-173. doi: $10.1007 / \mathrm{BF} 01162859$

Ubide, T., and Kamber, B. (2018). Volcanic crystals as time capsules of eruption history. Nat. Commun. 9, 326-326. doi: 10.1038/s41467-017-02274-w
Ubide, T., Mollo, S., Zhao, J.-,x., Nazzari, M., and Scarlato, P. (2019). Sector-zoned clinopyroxene as a recorder of magma history, eruption triggers, and ascent rates. Geochim. Cosmochim. Acta. 251, 265-283. doi: 10.1016/j.gca.2019.02.021

Wager, L. R., and Brown, G. M. (1969). Layered Igneous Rocks. Edinburgh: Oliver and Boyd.

Wager, L. R., Brown, G. M., and Wadsworth, W. J. (1960). Types of igneous cumulates. J. Petrol. 1, 73-85. doi: 10.1093/petrology/1.1.73

Wang, K.-Y., Song, X.-Y., Yi, J.-N., Barnes, S. J., She, Y.-W., Zheng, W.Q., et al. (2019). Zoned orthopyroxenes in the Ni-Co sulfide ore-bearing Xiarihamu mafic-ultramafic intrusion in northern Tibetan Plateau, China: implications for multiple magma replenishments. Ore Geol. Rev. 113:103082. doi: 10.1016/j.oregeorev.2019.103082

Welsch, B., Hammer, J., Baronnet, A., Jacob, S., Hellebrand, E., and Sinton, J. (2016). Clinopyroxene in postshield Haleakala ankaramite: 2. Texture, compositional zoning and supersaturation in the magma. Contribut. Mineral. Petrol. 171, 1-19. doi: 10.1007/s00410-015-1213-9

Witt, W. K. (1995). Tholeiitic and high-Mg mafic/ultramafic sills in the Eastern Goldfields Province, Western Australia: implications for tectonic settings. Austral. J. Earth Sci. 42, 407-422. doi: 10.1080/08120099508728211

Conflict of Interest: HM was employed by the company Boliden FinnEx Oy.

The remaining authors declare that the research was conducted in the absence of any commercial or financial relationships that could be construed as a potential conflict of interest.

Copyright (C) 2020 Schoneveld, Barnes, Makkonen, Le Vaillant, Paterson, Taranovic, Wang and Mao. This is an open-access article distributed under the terms of the Creative Commons Attribution License (CC BY). The use, distribution or reproduction in other forums is permitted, provided the original author $(s)$ and the copyright owner(s) are credited and that the original publication in this journal is cited, in accordance with accepted academic practice. No use, distribution or reproduction is permitted which does not comply with these terms. 